\title{
SIMPOSIUM SOBRE «EVANGELIUM VITAE Y DERECHO» Roma, 23-25 de mayo de 1995
}

\author{
Pedro M. ${ }^{a}$ Garín Urionabarrenechea
}

El 25 de marzo de 1995 el Papa Juan Pablo II publicaba la Carta Encíclica «Evangelium Vitae». Conmemorando el primer aniversario de su nacimiento, los días 23-25 de mayo se celebró un Simposio en la Ciudad del Vaticano, organizado conjuntamente por el Pontificio Consejo para la Interpretación de los Textos Legislativos, el Pontificio Consejo «Pro Familia» y por la Pontificia Academia «Pro Vita», bajo el epígrafe «Evangelium vitae e Diritto».

Si damos por cierta la información publicada por el L'Osservatore Romano, el Simposio congregó a cuatrocientos docentes del mundo del derecho, de la filosofía y de la ética, procedentes de cerca 150 Universidades e instituciones culturales de 26 países de diversos continentes del mundo ${ }^{1}$.

1. La apertura del Simposio corrió a cargo del Cardenal Alfonso López Trujillo, a la sazón Presidente del Pontificio Consejo para la Familia.

El Cardenal, intentando plasmar el hondo calado del Simposio, en el que se ven involucrados tres dicasterios de la Santa Sede, ofrece un elenco de datos, que caracterizan «con una tristísima peculiaridad, la expansiva cultura de la muerte». Por primera vez en la historia del mundo el delito es considerado como derecho: cincuenta millones de abortos «legales», consumados en un año; eliminación sistemática de niños, aun nacidos, sacrificados en obsequio a las leyes demográficas; intervenciones directas de los Jefes de Estado por bloquear iniciativas parlamentarias que tienden a restringir en ciertas condiciones la legalidad del aborto; férrea voluntad de introducir o alargar la legalización del aborto en legis-

1 Las fuentes de esta memoria son los textos entregados a los congresistas, las crónicas del L'Observatore Romano y las notas del autor; OR., 29 de mayo 1996, 6. 
laciones que hasta hoy no lo admitían; enconamiento penal para quienes pacíficamente se manifiestan contra el aborto; legalización de la eutanasia.

Se subraya la degradación en la que caen «todas aquellas democracias que vacían al hombre de sus valores éticos fundamentales y dan vida a sociedades enfermas "en el corazón" y "en la conciencia", hasta el punto de favorecer la extensión de la cultura de la muerte como fenómeno social».

El simposio - manifiesta el Sr. Cardenal- busca como objetivo reflexionar acerca de la incidencia que los principios morales sancionados en la Encíclica tienen en el mundo de la justicia, en el concepto mismo de la justicia, en el mundo académico universitario y legislativo, en pro de la tutela de la verdad objetiva sobre la persona humana y sus derechos fundamentales, el primero de ellos, el derecho a la vida.

Mons. Julián Herranz, Presidente del Pont. Consejo para la Interpretación de los Textos Legislativos, por su parte, es quien delinea los cauces de la reflexión con su título introductorio: La estructura moral de la libertad.

A nuestro entender, su exposición abarca dos apartados intrínsecamente unidos entre sí:

a) La constatación, tanto desde el punto de vista filosófico como jurídico, de negar la existencia de una verdad ontológica acerca del hombre, fruto del empirismo jurídico, base de algunas legislaciones, que está llevando a un lento, pero progresivo empobrecimiento de todo el sistema jurídico.

Este dato histórico, según Mons. Herranz, se prueba confrontando las legislaciones y la tutela de los derechos fundamentales de la persona, el más importante, sin duda alguna, el derecho a la inviolabilidad de la vida humana. «Frente a las proclamaciones universales (de los derechos humanos), y, por lo tanto, válidas para la totalidad de los individuos y de los Estados, debemos registrar en el mundo posiciones ideológicas y legislaciones civiles claramente contrarias. El graso equívoco está en la corrupción del concepto de legalidad que a veces se crea, cediendo a la tentación de entender el hombre, no en su efectiva realidad, en su esencia natural, sino en la forma que mejor se adecua a ciertas formaciones ideológicas, construidas por desgracia sobre mayorías numéricas o bajo las presiones de los "lobbies". En esta dinámica "todo es pactable, todo es negociable" (EV. n. 20), incluso los derechos, cuya atribución le viene de la voluntad de los otros, negando la existencia de unos derechos inherentes a su misma 
naturaleza. Se traiciona así la verdad ontológica sobre el hombre, sobre su existencia. Por ello, el Santo Padre insiste siempre en afirmar que en el corazón del hombre está inscrita una ley moral, que en cuanto ley natural inscrita en el corazón del hombre, es punto de referencia normativa de la misma ley civil (EV. n. 70). Esta ley constituye el fundamento de la Declaración universal de los derechos del hombre. Mas, he aquí, la paradoja: en el siglo, en el que se ha escrito una tal Declaración que tutela los derechos objetivos y no volubles precisamente porque son universales, por lo tanto, no ligados al vaivén de la opinión de las gentes, sucede que algunas legislaciones positivas terminan por negarlos, una tras otra». ¿Cómo superar esta realidad destructiva de la humanidad?

b) La defensa de la estructura moral de la libertad humana frente a las dos grandes utopías ideológicas, que se han asentado como sistemas políticos a escala mundial: la autopía totalitaria de la justicia sin libertad y la autopía radical-liberal de la libertad sin verdad. «Totalitarismos de signo opuesto - los definió el Papa hablando en la Universidad de Vilnius en septiembre de 1993- y democracias enfermas que han desordenado la historia de nuestro siglo» (OR. 5.9.1993).

La libertad sin la verdad — prosigue— madurada en el «hábitat» filosófico del iluminismo ha encontrado su herramienta en el positivismo jurídico, merced al cual los gobernantes de hoy, como Pilato, quieren acallar la propia conciencia no en la verdad objetiva, que asegura la racionalidad de la norma, sino en la verdad convencional, estadística, fruto de la absoluta autonomía del hombre que, olvidadizo de su condición de criatura, opina ser «criterio y norma» de sí mismo. En esto reside la falacia de la autopía jurídica y política de la libertad sin verdad. He dicho falacia porque todo este ordenamiento filosófico social tiene como base el principio apriorístico que «una verdad común y objetiva sea de hecho inaccesible, como se lee en el EV. (n. 68). Me parece lícito preguntarse: ¿puede decirse que esta cultura basada en el absoluto relativismo moral sea una verdadera cultura democrática? Aún más, ¿que sea una verdadera cultura en el sentido más noble de la expresión? No lo es. Por ello, reproducimos las siguientes palabras de la EV.: «El valor de la democracia se mantiene o cae con los valores que encarna y promueve (...) En base de estos valores no pueden estar provisionales y volubles «mayorías» de opinión, sino sólo el reconocimiento de una ley moral objetiva que, en cuanto «ley natural» inscrita en el corazón del hombre, es punto de referencia de la misma ley civil» (n. 70). 
A estas desviadas interpretaciones de la democracia, seguidas por las expansivas ideologías agnósticas y permisivas, se oponen, como atestiguan numerosos autores, Maritain, Del Noce, Cotta o Hervada, las interpretaciones de los clásicos, para quienes «la democracia no es una indiscriminada afirmación de la absoluta autonomía del hombre, sino un ordenamiento social de libertad delimitada por el orden natural». Límites, por lo tanto, no impuestos, autoritariamente desde fuera (tendencia totalitaria) o mediante un simple y omnicomprensivo acuerdo pacticio (tendencia liberal-radical), sino por un orden que tiene un fundamento intrínseco: ética y derecho natural. Límites — ha subrayado- determinados por la misma estructura ontológica de la persona humana: por su naturaleza, es decir, de ser no sólo animal e instintivo, sino inteligente, libre, portador de valores morales y con una dimensión trascendente y religiosa del espíritu que no puede ser ignorada, y mucho menos, violada, por ningún sistema jurídico o político.

Termina Mons. Herranz su exposición, afirmando que la misma Declaración Universal de los Derechos Humanos es un ordenamiento social de libertad que afirma la posibilidad «aún más, la realidad de una verdad objetiva sobre el hombre y sus derechos, el primero, entre todos, el derecho a la vida» y que la negación de la verdad objetiva sobre la dignidad de la persona y sobre el valor de la vida «equivaldría a destruir el fundamento más profundo de la legalidad legislativa y del estado de derecho, abriendo la vía al progresivo desarrollo de una sociedad salvaje ${ }^{2}$.

Mons. Elio Sgreccia, Vice Presidente de la Pontifica Academia por la «Vida», en este cuadro del empirismo jurídico reinante, ha denunciado el peligro que conlleva en el debate bioético la separación entre la moral privada y la ética pública en el ámbito, así llamado, pluralismo ético. De ahí, la urgencia de afirmar la legitimidad de un discurso ético en el ámbito social y su relevancia en el mundo jurídico. De hecho, es inadmisible que, no obstante el continuo progresar de la bioingeniería, el sistema jurídico no haya aún encontrado la normativa precisa de regular las diversas aplicaciones de las conquistas científicas en este sentido, sobre todo, para tutelar la dignidad de la persona. No reconocer, por otra parte, la relevancia de la cuestión ética tanto en el ámbito social como jurídico significaría «avalar la tendencia, según la cual la ley tiende siempre a sustituirse a la moral o, sin rodeos, ser su fundamento constitutivo. En consecuencia, la moral viene a ser siempre considerada socialmente irrelevante en nombre del pluralismo o de lo «privacy» $^{3}$.

2 OR, 24 de mayo 1996, 10.

3 OR., 26 de mayo, 1996, 7. 
2. Con estas premisas de presentación de la temática, tuvo lugar la primera relación por parte de Mons. Carlo Caffarra, titulada «Essere por la Vita: annuncio cristiano e verità della persona nella continuità della Veritatis Splendor ed Evangelium Vitae».

Mons. Caffarra comienza su disertación, distinguiendo dos apartados:

1. ${ }^{\circ}$ Vía teórica de la Encíclica «Veritatis Splendor» y de la «Evangelium Vitae»; 2. ${ }^{\circ}$ Encuentro doctrinal de ambas encíclicas.

1. ${ }^{\circ}$ En la EV. se nos dice que «perdiendo el sentido de Dios, se tiende a perder también el sentido del hombre» (n. 21).

1.1. Este eclipse del sentido de Dios y del hombre conlleva a la violación sistemática del respeto de la vida humana (abortos, eutanasia).

El hombre de la modernidad, al descubrirse como sujeto libre, ha hecho la así llamada tergiversación antropológica, hacia la inmanencia subjetiva, sin trascendencia vertical. Destruyendo la relación con el «Logos» de la realidad como razón fundante de su propio ser: «Soy o no antes Dios», el hombre ha querido afirmar su soberanía absoluta (SV. n. 35). Si se es soberano, el morir depende del mismo ser del que depende el vivir (dominio del nacimiento y de la muerte). Nadie está por encima del hombre y es él el único y solo juez que pueda dictaminar cuándo su vida es digna. Consiguientemente, el hombre se considera como señor del bien y del mal (SV. nn. 32, 35), al que se le confía el deber de justificar la realidad misma.

Esta actitud cultural revela, en primer lugar, la negación de la libertad al no reconocer su vínculo constitutivo con la verdad (EV. n. 19 y SV. n. 33). La verdad del ser se reduce a la conciencia del individuo (concepción radicalmente subjetivista), que, a su vez, es sustituida por el consenso (la mayoría). En segundo lugar, como consecuencia del no reconocimiento de la verdad, una experiencia de libertad autofundante de sí misma, cuyo criterio objetivo no va más allá de sí misma (la verdad es creación de la libertad) (SV. n. 35) y cuyo fin es la consecución del propio bienestar material (EV. n. 23).

1.2. En la SV. se nos dice que las exigencias ineludibles de la dignidad personal de cada hombre están tuteladas por las normas morales, que prohíben sin excepción los actos intrínsecamente malos (SV. nn. 90-95) y que la firmeza de la Iglesia en defenderlas se debe en cuanto «Está sólo al servicio de la verdadera libertad del hombre» (SV. n. 96). He aquí, la conexión entre libertad y verdad.

El «mal intrínseco» es aprehendido por la razón en el mismo ser del hombre ( ratio practica»), e independientemente de las intenciones y circunstancias de quien actúa, afecta al ser mismo de la persona (SV. nn. 79-83). 
De ahí, la intrínseca ligazón entre «ser», «libertad» y «verdad». No hay «ser» sin «libertad»; mas esta libertad, no es ilimitada, tiene sus límites conocidos por la razón práctica. Si todo tiene el mismo valor ( = todo es indiferente) la existencia queda reducida a un juego, en el que se tiende a negar la vía orientadora del intelecto (la razón) al ser (la verdad): el criterio de la verdad sobre el hombre sustituido por «el criterio de la eficiencia, la funcionalidad y la utilidad» (EV. n. 23).

2. ${ }^{\circ}$ Encuentro doctrinal de ambas Encíclicas: en la afirmación de la dignidad de la persona.

En la SV. se nos dice que la libertad depende fundamentalmente de la verdad (SV. n. 34) y en la EV. se enseña que «En realidad, sólo delante del Señor el hombre puede conocer su pecado y percibir toda su gravedad» (EV. n. 21).

La verdad (el bien moral objetivo), que la razón humana puede conocer (SV. nn. 32 y 40), fundamenta la norma en pro de promover el bien perfecto y completo de la persona misma. Esta verdad no está en contradicción con la libertad; al contrario, ofrece las necesarias referencias a cada uno a fin de que pueda juzgar rectamente su elección en orden a su bien perfecto y completo (SV. n. 35).

El ponente manifiesta que en el mundo actual se han aposentado dos actitudes erróneas: una tendencia agnóstica y/o, una tendencia pelagiana.

Citando a Pascal, que afirma que la ruptura relacional hombre-Dios conlleva a que el hombre se desprecie a sí mismo, manifiesta la necesidad de vivir la experiencia hombre-Dios. ¿Cómo? Anunciando el Kerigma del Evangelio, es decir, a Cristo, ayer, hoy y siempre (SV. n. 25). ${ }^{4}$

3. Tras la ponencia se abrió el debate, que giró alrededor de este interrogante: ¿Cómo puede exponerse en el ámbito internacional esta nuestra cultura moral?

Se requiere un proceso - responde el ponente - que convenza que con una antropología individualista, renunciando a la verdad objetiva, plasmada en la acción política, presionada por la base, árbitro moralizante de la sociedad, es imposible alcanzar una vía justa. ¿Cómo ha sido posible el derrumbamiento de ciertas evidencias, v.g., el matrimonio, la familia, etc.? Algo ha pasado. La vía que haga evidente nuestro anuncio no es una demostración documental, sino un compromiso total por la reeducación del ser humano. Esta es la función de la Iglesia.

4 OR., 26 de mayo 1996, 7. 
4. A la tarde, se leyeron dos comunicaciones. La primera de ellas, por el prof. de Historia del Derecho Público de la Iglesia en la Universidad de Strasbourg, Mons. Rolando Minnerath, cuyo título era: "Prospettiva della tradizioni giuridiche circa il diritto alla Vita nei dibattiti internazionali». La segunda, por Mons. Mounged El-Hachem, docente de Derecho Islámico en la Pont. Univ. Lateranense, titulada: "L'esperienza giuridica Islámica de il diritto alla Vita».

Mons. Minnerath desarrolló su comunicación en tres apartados:

1. La protección de la vida en el derecho internacional.

Según el relator, el derecho inalienable a la vida de toda persona humana encabeza las Declaraciones y Convenciones internacionales. El problema estriba cuando se intenta determinar el término «persona». Se nos dice entonces que «persona» se es a partir del nacimiento. Esta es la interpretación oficial dada en 1979 por la Comisión europea de los derechos del hombre, referente al art. 2 de la Convención europea de los derechos del hombre de 1950.

La Comisión, sin embargo, no excluye que el feto no tenga derechos a una cierta protección, v.g., el derecho a la herencia (Causa Brueggermann Sheuten contra Allemagne). En la Convención americana relativa a los derechos del hombre de 1969, en la que los Estados Unidos no se avino a firmarla, se llega a una fórmula de compromiso, en la que se establece, si bien tímidamente, que el derecho de toda persona a la vida (....) debe ser protegido por ley, en general, a partir de la concepción (art. 4), dejando a cada Estado-miembro la decisión de determinar en su legislación interna cuándo comienza la vida.

Cita también la Declaración de los derechos del hombre en el Islam adoptada en El Cairo, en 1990, por los 52 Estados miembros de la Organización de la Conferencia islámica. Esta Declaración afirma que la vida es un don de Dios y el derecho a protegerla (art. 2a), pues la Sharia prescribe la preservación de la vida desde el primer momento hasta su fin, fin que es determinado por Dios (art. b) y en el art. se lee que el niño tiene derechos desde el momento de su nacimiento, pero que el feto y la madre deben recibir una protección y un cuidado especial.

En ningún texto universal o regional, el derecho a la vida es un derecho absoluto. Se alude a la pena capital, legalmente aplicada, como se lee en el Pacto 1966, art. 6,5; la Convención europea (art. 2,2); la Declaración islámica (art. 2b). El estatuto del embrión y del feto no está determinado en las Convenciones internacionales. A cada sistema jurídico, incluso a cada legislador nacional, se le ha confiado concretar las condiciones, en las que la vida antes del nacimiento debe ser «protegida». 
Se nos dice que la primera gran ruptura vida se produjo en 1920 por la URSS de Lenin, seguido del paréntesis del régimen nazi, con sus leyes eugenésicas y el genocidio.

En el mundo soviético iba a nacer una nueva concepción del derecho - manifiesta el relator-, formando la familia de los derechos socialistas, que incluso han dejado sus huellas después de 1989. Este derecho ha sido el primero en despenalizar, después a alentar el aborto, y, finalmente, a planificar por parte del Estado la regulación de los nacimientos y la práctica del aborto.

Desde la Suecia de 1938 hasta la España en 1985, la mayoría de los países occidentales han despenalizado el aborto, bajo el pretexto de evitar las prácticas clandestinas y de someterlo a un control social. En la última década, bajo las presión de los diversos grupos, la opinión ha evolucionado insensiblemente desde la despenalización a la banalización moral del aborto, hasta su reivindicación como derecho de las mujeres de disponer libremente de su cuerpo. Desde esta óptica el aborto es un hecho que queda anclado en la esfera meramente privada. Estas concepciones extremas se han hecho patentes, con más o menos insistencia, en las Conferencias internacionales, de forma notable, la de El Cairo (1994) y de Beijin (1995).

2. Los sistemas jurídicos y el respeto a la vida.

a) Los países de Europa y de América, sellados por la cultura cristiana, el derecho romano-germánico o la commom law, carecen de homogeneidad. En las constituciones de Irlanda y en algunos países latino-americanos se proclama el derecho del ser humano a la vida desde la concepción. En Alemania, el tribunal constitucional de Karsruhe ha dictado una sentencia en 1975, confirmada en 1993, según la cual, el respeto a la vida comienza a partir de la concepción. El aborto es considerado como delito, si bien el Estado renuncia a penalizarlo.

En el otro extremo, la Corte Suprema de los Estados Unidos ha legalizado el aborto, estableciendo en la causa Roe/Wade en 1973 que la vida humana debe entenderse a partir del nacimiento. El 10 de abril de 1996, el Presidente vetó la ley del Congreso que prohibía el aborto después de las veinte semanas, considerándolo como delito de infanticidio.

Ciertos Estados de Europa central y oriental conllevan las huellas de las legislaciones comunistas favorables al aborto, como Eslovenia, que lo considera como derecho en su Constitución de 1991 (art. 55).

b) Los Estados islámicos son los más homogéneos en los debates internacionales. El Corán prohíbe taxativamente el infanticidio (Azora, 6,$141 ; 17,33 ; 60 ; 81,5)$. El hecho que sea menos explícito respecto a la vida del que va a nacer, explica la tolerancia de algunos Estados musulmanes en materia del aborto bajo determinadas condiciones. 
En Africa sub-sahariana, donde la cultura, la naturaleza y las costumbres vigen aún, los conflictos referentes al matrimonio tradicional y a la familia se regulan por los arbitrajes tradicionales, más que por los tribunales. La vida del «nasciturus» es generalmente un valor que hay que respetarlo.

c) En el grupo de las grandes civilizaciones asiáticas, el horizonte normativo es el dharma, o la verdad eterna del orden cósmico, en el que los individuos están insertos, cada uno según su categoría social (las castas). El dharma no conoce la idea de derecho subjetivo. En el flujo continuo de los renacimientos, la persona y la vida no cuentan. No obstante, el budismo ofrece la perspectiva de la emancipación del ciclo de las existencias transitorias por el acceso al nirvana y enseña el respeto de los seres vivos. El hinduismo y el budismo animan a la virtud de la compasión por los seres débiles, considerando inmoral la violencia al «nasciturus» como al anciano. Sin embargo, en India, la legislación tolera la práctica del aborto a gran escala, así como el infanticidio, sobre todo, de las hijas.

d) En el mundo de la China, Japón, Corea, Viet-Nam el pensamiento de Confucio, basado en la persuasión, autocrítica, moderación y conciliación, tiene más calado que las leyes positivas. Es la idea de una armonía cósmica, en la que el hombre debe insertarse por la virtud y la moralidad de sus acciones. Se desconoce la idea de derecho subjetivo.

Desde esta óptica cultural, en China, la vida no tiene valor absoluto. La limitación forzada de los nacimientos y el infanticidio eran prácticas corrientes desde la era imperial. A partir de 1982 una liberación planificadora del Estado ha permitido un despegue económico en las regiones costeras, teniendo como consecuencia el desarrollo de un individualismo violento. Desde 1958 los autoridades han lanzado campañas en pro de la limitación de los nacimientos. La cuarta, en 1979, demanda a un $20 \%$ de las parejas urbanas y a un 5\% de las rurales que limiten su descendencia a un hijo. Las familias con un solo hijo se ven favorecidas. Estas medidas pueden llegar hasta la esterilización forzada. Medidas que van acompañadas por la práctica del aborto y del infanticidio de las hijas para poder transmitir el nombre a un descendiente varón.

En la tradición japonesa, el aborto, cuya primera condena se encuentra en el Código penal de inspiración francesa de 1880, es considerado como inmoral, pero no sancionado por ley. Bajo los Tokugama, siglo XIX,s., el infanticidio se extendía por causa de la pobleza ambiental. La ley de Protección eugenésica de 1948, aún en vigor, invalida el derecho penal y legaliza el aborto. En Japón no se conoce la idea de derecho subjetivo. El individuo adquiere su identidad social en el seno de su familia, el «ie». El derecho es considerado como una coacción de los dirigentes. Las gen- 
tes honestas deben observar los «giri», es decir, las reglas morales arraigadas a la condición de cada uno.

3. ¿Cuál es el consenso internacional?

El pensamiento occidental es faro orientador de los debates internacionales. Los herederos de la «Ilustración» no soportan la idea de que sus conceptos no sean aceptados como universales, cuando al mismo tiempo se expresa por otros continentes el deseo de renegociar una Declaración universal de los derechos del hombre en busca de una vía más respetuosa de la diversidad de los sistemas culturales. La negociación internacional sobre el aborto, intervención sobre el genoma y la eutanasia se pretende en el ámbito universal y regional.

No se debe olvidar que en las reuniones internacionales, los Estados están representados por sus funcionarios, no por los pueblos, las culturas, las civilizaciones, las religiones. Las Conferencias internacionales son acontecimientos políticos.

En dichos ámbitos se busca la vía del consenso, pero como su obtención en el fondo es un ejercicio imposible, se impone, a menudo, satifascerse de un consenso meramente formal. La evolución de las normas internacionales se revela más en lo que no se dice, en los silencios, en los deslizamientos del sentido de las mismas palabras que en las innovaciones espectaculares.

He observado ya - dice el relator-que los Estados nacionales se abstienen de definir los conceptos, a pesar de todo, esenciales. En el ámbito internacional es inevitable que el sentido dado a una misma palabra varíe en los diferentes contextos culturales y jurídicos. Así, el informe explicativo (n. 23) del Proyecto de la Convención europea de bioética constata que los términos de «persona» y de «ser humano» no están definidos, al no existir entre los Estados miembros del Consejo de Europa unanimidad en su definición, conviniendo dejar al derecho interno el sentido eventual de dichos términos. El informe añade «no obstante ha sido constatado como principio generalmente aceptado que la dignidad humana debe ser respetada desde el comienzo de la vida».

Otra tendencia es la de erosionar intencionadamente conceptos en un tiempo indiscutidos. Así, el concepto de familia y de la maternidad.

A los cinco años de la Convención sobre la eliminación de la discriminación respecto a las mujeres de 1979, en la que no se vislumbraba un derecho al aborto, en la Conferencia de México sobre la población, el acento recae en el control de la natalidad como método de la planificación familiar. En 1994, en la Conferencia de El Cairo sobre la población y desarrollo, se alzan voces por abandonar el concepto de «familia» como célula base de la sociedad. Se reconoce «diferentes tipos de familia», proponiendo entre los derechos de la mujer el derecho de decisión, 
eventualmente sola, respecto a la procreación. Se presiona por reconocer como derecho, sin restricción, a escala mundial el derecho al aborto. En Beijin en 1995 no se hace mención alguna de la familia. Más aún, se considera que la familia y la maternidad son obstáculos a la autorealización de las mujeres. Se ha intentado el reconocimiento de la existencia de cinco «géneros» entre los seres humanos, en lugar de los dos sellados por el Creador.

De la misma forma, dos nuevos conceptos aparecen en El Cairo: «reproductive health»y «reproductive rights» («salud reproductiva»y «derechos reproductivos») al margen del matrimonio o de la pareja. La Conferencia de Beijin define la «salud reproductiva» como «un estado de absoluto bienestar físico, mental y social... en todos las campos relacionados con el sistema reproductivo» (n. 94). Se excluye el aborto como método de planificación familiar $(7,24)$; pero forma parte de los derechos reproductivos (7.6)

La imprecisión es, a veces, una condición de la negociación internacional. El proyecto de la Convención europea de bioética mantiene deliberadamente silencio sobre la naturaleza jurídica del embrión humano. El legislador francés ha establecido en 1994 que el ser humano no goza de la cualidad de persona desde de su concepción. Otro país ha propuesto que sea cada nación, conforme a sus «valores espirituales» quien responda a la cuestión «del comienzo de la vida humana». Si bien la Convención propone excluir toda intervención sobre el genoma humano, que tenga como objeto modificar sus caracteres genéticos (art. 14), no ha resuelto el problema de la investigación sobre el embrión humano (art. 17). La misma imprecisión en cuanto a la definición del embrión humano se refleja en el Plan de la Declaración sobre la protección del genoma humano preparado a solicitud de la Unesco por un Comité internacional de bioética.

Los valores reconocidos como el de la dignidad humana pueden también servir para encubrir actos contrarios a la misma. En abril 1991, el Parlamento Europeo presentó una proposición de resolución sobre los cuidados paliativos, en la que se intenta reconocer al médico un derecho de asistencia al enfermo para poner fin a su existencia. La Comisión competente ha reforzado la proposición, precisando que es al médico a quien le pertenece satisfacer todas las demandas del enfermo cuando los cuidados paliativos dejen de ser útiles. El motivo de esta proposición es que la enfermedad puede terminar por destruir toda la dignidad a una persona y, por consiguiente, privarle de su dignidad. En los Países Bajos la eutanasia se practica, a pesar que una proposición de ley en 1987 en pro de la despenalización de la eutanasia fue rechazada. En USA, dos Tribunales federales de Apelación la han legitimado, llamándola «suicidio asistido». 
El ponente termina su exposición aludiendo a la presencia y doctrina de la Iglesia en esos foros internacionales y transcribiendo el nro. 71 de la EV, en el que se enseña: «... la ley civil debe asegurar a todos los miembros de la sociedad el respeto de algunos derechos fundamentales, que pertenecen originariamente a la persona... Entre ellos el primero y fundamental es el derecho inviolable de cada ser humano inocente a la vida.... Si la autoridad pública puede, a veces, renunciar a reprimir aquello que provocaría, de estar prohibido, un daño más grave, sin embargo, nunca puede aceptar legitimar, como derecho de los individuos - aunque éstos fueran la mayoría de los miembros de la sociedad-, la ofensa infligida a otras personas mediante la negación de un derecho suyo tan fundamental como el de la vida».

La segunda comunicación de Mons. Paul-Mounged El-Hachem, «La experiencia jurídica islámica y el derecho a la vida», nos dice que en el tercer proyecto de la Declaración de los derechos del hombre en Islam, adoptado en El Cairo, 4 de agosto de 1990, aún no promulgado, en su art. 2 se constata: a) La vida es un don de Dios y el derecho a la vida está garantizado a cada ser humano; b) Está prohibido el recurso a los medios que pudieran conducir al genocidio; c) La protección de la vida humana, conforme a la voluntad de Dios, es un deber según la Chari'a.; d) La seguridad de no sufrir daños corporales es un derecho garantizado, y el Estado tiene la responsabilidad de proteger este derecho que no se puede violar, salvo si la Chari'a lo permita. Estos principios están reconocidos en las fuentes islámicas: el Corán, la Sunnah y la Jurisprudencia islámica.

Seguidamente el ponente hace alusión a casos concretos:

1. La Jihad y el martirio.

Todos los juristas están de acuerdo que es un deber combatir por Dios.

Aun reconociendo el sentir de algunos juristas que el combate por Dios no busca dañar a los creyentes, ni matar a los adversarios y su fin es convertir a los enemigos al Islam, es necesario, también, reconocer que en este combate la libertad de adhesión al Islam brilla por su ausencia.

Es verdad, sin embargo, que el Jihad predicado por el Islam no autoriza matar. La guerra tiene sus reglas que hay que respetarlas. Así, el art. 3 del tercer proyecto de la Declaración de los derechos del hombre en Islam de la L'OCI formula estas reglas: «No está permitido, en el caso de la utilización de la fuerza o de conflicto armado, matar a las ancianos, mujeres y niños. Los heridos y los enfermos tendrán derecho a la asistencia sanitaria; los prisioneros de guerra tendrán derecho al alimento, abrigo, y vestidos. Se prohíbe la mutilación de cadáveres. Es un deber el intercambio de prisioneros». Todo esto indica un respeto a la vida, si no es radical, al menos, bastante importante. 
Desde este prisma, el Islam, que persigue salvar la vida de los creyentes, no impide glorificar a los mártires, que desean morir por sus creencias. Es necesario, no obstante, reconocer que en el derecho islámico, el martirio no hay que buscarlo por el martirio mismo. La muerte no puede ser deseada como tal, conforme a la palabra de Mahoma: «No deseéis la muerte, pero si la encontráis, sed firmes».

Si el deber del mulsumán es velar por su propia vida y actuar con el enemigo según la Chari’a divina, ¿cómo debe comportarse frente a la vida del ser humano?

2. El control de la natalidad.

El ponente, citando los textos sagrados, dice que la limitación de los nacimientos es considerada naturalmente como debilitamiento de la nación islámica, que tiene necesidad de capital humano para luchar contra sus enemigos, pasados y presentes. Es, igualmente, considerado como castigo divino: «Os probaremos con algo de temor, de hambre, de disminución de vuestros bienes, personas y frutos» (Corán, 2,155). Aun más, el hecho de la limitación de los nacimientos es concebido como complot de los colonizadores contra la nación islámica.

Teniendo en cuenta — dice- que la ley islámica impulsa a multiplicar los nacimientos, considerando que son una gracia eminente y un don superior que Allah otorga a sus servidores; que las tesis a favor de la limitación son contrarias a la sana naturaleza humana («fitra»); que sus partidarios constituyen un grupo que confabula contra los musulmanes en general y contra la nación árabe-musulman, en particular, de forma que puedan imponer sus tesis colonialistas a los países (musulmanes) y sus habitantes, y porque en estas tesis existe una especie de prácticas dignas de la Jâhilyya, una malvada opinión del mismo Allah y un debilitamiento evidente de la sociedad islámica, que se funda en el nombre y la solidaridad de sus rocas humanas, el Consejo ha decidido que es absolutamente ilícito limitar los nacimientos. (Resolución n. 42 en la fecha del 3.4.1396, en la semana árabe de la Rábita (La Mecque).

El ponente dice que los partidarios en pro de la limitación tienen a bien recurrir a versículos que sostienen la cualidad contra la cantidad (Corán 102:12; 4:3; 64:14-15), a los Hadiths que van en esta línea y parecen, en nombre de una cierta clemencia, permitir el control de la natalidad. En definitiva, la ley de la necesidad legitima la infracción de las prohibiciones, a menudo, invocada por la jurisprudencia.

El Corán inculpa, en realidad, a una costumbre del infanticidio (wa'd) practicado en la Jâhiliayya por temor a pobreza y a la miseria (imlâq), y exalta a Allah como gran el Proveedor: «Quien da el sustento, el Dueño de la fuerza, el Inamovible» (51:52); «no mataréis a vuestros hijos por temor de la miseria: nosotros proveeremos a vosotros y a ellos» $(6,151)$. 
El ponente dice que la actitud del Islam respecto al control de la natalidad puede resumirse en una decisión en cuatro puntos tomada por la Academia de investigaciones islámicas, en la reunión tenida en El Cairo, en la que han participado representantes de 35 países musulmanes en 1965:

«1. El Islam impulsa el aumento de la prole y su multiplicación, porque refuerza la comunidad islámica tanto en lo social, económico y militar.

2. En caso de necesidad, nadie impondrá la planificación de la prole, los esposos deben atenerse a esta necesidad, según su conciencia individual y sus creencias.

3. Se prohíbe, según el derecho musulmán, promulgar leyes que impongan a la gentes la limitación de la prole bajo cualquier forma.

4. El aborto, en aras de la limitación de la prole, no deberá practicarse ni por los esposos ni por terceros. La Academia recomienda la concienciación y ayuda a los ciudadanos» (Décision dans Bar: Siyassat, p. 450. En otras faatwas, pp. 451-455. cf. Sami, ídem, p. 53).

\section{El aborto.}

En realidad, lo anteriormente dicho es válido respecto al aborto. Es necesario, sin embargo, reconocer que el aborto encierra una nueva responsabilidad a los ojos del Islam. El art. 7 de la Declaración de los derechos del hombre en Islam de la L'OCI afirma: «Todo niño, desde el momento de su nacimiento, tiene derecho a los cuidados apropiados, a la educación, al sostenimiento material y moral de sus padres, de la sociedad y del Estado. La madre y el feto recibirán protección y tratamiento especial durante el período de la maternidad» (en Conscience et liberté 41/1991, p. 112). ¿Qué entiende el Islam por feto?

El ponente, tras afirmar la creencia del Islam en la formación progresiva del feto y en la insuflación tardía de la vida en este feto, cita con Saleh al Fawzan la resolución emitida a este respecto por el consejo de la Asamblea de los Grandes Doctores de la ley, en fecha 20-6-1407 (1987/1988):

«1) No es lícito expulsar el embrión en ninguna de las etapas del embarazo, a no ser que una causa conforme a la ley lo justifique, pero siempre en los límites más estrictos del caso examinado.

2) Si el embrión se encuentra en su primera etapa, a saber, en sus primeros cuarenta días, y si existe, a raíz de su expulsión, algún beneficio reconocido por la ley o la necesidad de evitar algún daño, esto es lícito. Mas la expulsión, en este primer período, por la simple razón que hubiera dificultad de educar a los niños o que se temiera ser incapaz de poder sustentar e instruir, o bien porque se tratara de su porvenir o porque se quisiera limitarse a los hijos, que los esposos han engendrado, (esto) no es lícito. 
3) No es lícito expulsar el embrión desde que está en un estado de adherencia (!alaqa) o de masa floja (mudga), hasta que un equipo médico agregado no haya determinado que su conservación conlleva peligro para la salud de la madre, al temerse su muerte: es lícito expulsarlo después de haber agotado otros medios posibles para evitar el peligro corrido por la madre.

4) Cuando la tercera etapa (de la formación) ha terminado y cuando el embrión está al final de su cuarto mes, no es lícito expulsarlo hasta que un equipo de médicos especialistas y agregados no haya establecido que la conservación misma del feto en el vientre de su madre causaría la muerte de ésta, y esto después de haber agotado todos los medios posibles para salvaguardar la vida.

La autorización de expulsar el feto en tales condiciones es concedida por evitar, entre dos males, el más grave y por garantizar el mejor de los dos bienes (a considerar)». (en L'hebdomadaire Akhbâr al-Alam al-islàmi, La Mecque, 5-9-94).

El aborto, por lo tanto, está prohibido; los casos difieren durante los cuatro primeros meses de la vida uterina o después; según sea el caso, se sanciona en el ámbito religioso, penal y temporal, sanciones determinadas por la Ley islámica. feto?

¿El aborto es permitido cuando se descubre una deformación del

El ponente cita la opinión del Consejo de la Academia de Derecho Islámico de la Liga del Mundo Islámico, en su 12 sesión habida en La Mecque, sábado 10 al 17 e febrero 1990: «Si el feto ha llegado a los 120 días no es lícito expulsarlo, aun en el caso de un diagnóstico médico que prevé que su conformación será defectuosa; a no ser que un informe de un equipo médico compuesto por especialistas certifique que su conservación constituye un peligro para la vida de la madre....». En el caso que sea antes de los 120 días, es lícito expulsar el feto siempre que el informe médico certifique que no hay esperanza alguna de tratamiento y curación y que, si nace, conocerá una de las vidas más dolorosas plagada de sufrimientos para él y su familia (en L'hebdomadaireAkhbâr al-Alam alislàmi, La Mecque, 5.9.1994).

4. La esterilización.

Como vemos, el aborto está sancionado y autorizado solamente en el caso de necesidad (peligro de la vida de la madre). ¿En el caso del descubrimiento de algunas taras hereditarias en una concepción posible, se autoriza no sólo la expulsión del feto por estado de necesidad, sino, también, para prevenir tal situación, el recurso a la esterilización?

El Cheikh de la Universidad Al-Azhar responde a este interrogante: Cuando nos remitimos al Sto. Corán y a la Noble Sunna, no encontramos 
en ninguno de estos textos un texto concreto claro que prohíba la esterilización. Mas los textos, de carácter general, tanto en el Corán como en la Sunna la rechazan y la prohíben.

«Aplicando tales textos, la asamblea de jurisconsultos declara, pues, que la esterilización está prohibida por la ley islámica si no existe necesidad alguna, en cuanto se trata de suprimir los nacimientos (pontenciales), lo que atenta a la necesidad de salvaguardar la reproducción de la especie (humana), una de las cinco necesidades que el Islam considera que constituyen las finalidades (maqâsid) esenciales de la legislación en sus cualificaciones ético-jurídicas» (en L'hebdomadaire Akhbar al-Alam al-islàmi, La Mecque, 5-9-1994).

El ponente manifiesta que no existe unanimidad en la praxis como en la doctrina respecto a la esterilización. Unos, la justifican en la Chari'a (en Sami, ídem. pp. 74-75; 80-81-82), otros, se oponen, basándose en la bondad de la creación (Corán 32:7). De hecho, el objetivo del Islam en sus actitudes, flexibles y maleables, es el de asegurar el bien del hombre. Es verdad, sin embargo, que los textos islámicos insisten continuamente sobre el respeto de la vida y la de la naturaleza, cuya alteración se considera como obra del diablo (Corán 4:118-119). Aun más, ciertas investigaciones de la genética moderna no se admiten por la jurisprudencia islámica, a no ser dentro de los límites de la moral islámica. Así, la inseminación artificial se admite en los casos de necesidad y conforme a las normas generales del matrimonio, de los derechos de paternidad y de maternidad y de la herencia.

Las recomendaciones de una conferencia sobre la procreación a la luz del Islam afirman a propósito de la inseminación artificial:

1) La licitud de la inseminación artificial cuando tiene como objetivo satisfacer la necesidad de la mujer casada que no concibe y la necesidad de tener un hijo por parte de su marido.

2) El primer método, por el que se toma el esperma de un hombre casado y se inyecta en el útero de su mujer, siguiendo ella misma el método de la inseminación interna, es un método permitido por la Chari'a, dentro de las condiciones generales establecidas y siempre que se confirme la necesidad de esta operación por parte de la mujer en pro de la concepción.

3) El tercer método, según el cual se toma el esperma y el óvulo de un hombre y de un mujer casados entre sí, y se les fecunda por la inseminación in vitro, después se transplanta el óvulo fecundado en el útero de la mujer donante del óvulo, es un método admitido, en principio, en tanto en cuanto tal; mas dadas las dudas que entraña, por las confusiones que la acompañan, no se debe recurrir mas que en el caso de necesidad extrema, habiendo asegurado los requisitos generales establecidos. 
4) El séptimo método, según el cual se toma el esperma y el óvulo de una pareja casada y después de la fecundación in vitro, se insemina el óvulo fecundado en el útero de la otra mujer del marido mismo, que se propone libremente por esta concepción, parece al Consejo de la Asamblea lícito, en el caso de necesidad y en las condiciones generales determinadas. (La procreation dans l'Islam, Conference tenue au $\mathrm{Ku}-$ weit, 24 de mayo 1983, p. 480-481).

Todos los demás casos son rechazados por respecto a la moral islámica.

En cuanto a la eutanasia, el ponente dice que lo que interesa es saber que el Islam tiene sus propias concepciones del comienzo y fin de la vida. Tiene su propia moral de la vida que esencialmente la respeta.

5. El sistema penal musulmán.

El ponente dice que los textos de la Chari' a admiten la ley de talión y tipifican como delitos, por ejemplo, el adulterio que da lugar a la flagelación, incluso para quien lo denuncia y no prueba, y en ciertas condiciones por la misma causa da lugar a la lapidación. Se considera como delitos el bandidaje, la insurrección armada y el atentado a la integridad física, que conlleva a la amputación.

En relación a pena capital, el Islam — dice — la defiende con el mismo vigor que defiende la vida.

Termina su comunicación diciéndonos que el Islam respeta ciertamente la vida como sagrada. Pero que tiene sus propias concepciones referentes al comienzo de la vida, su evolución y su fin, lo que refleja su actitud ante el aborto y ciertas conductas que representan para nosotros atentados a la vida. Tiene sus nociones propias que conciernen el sistema penal, el derecho y el mismo deber de la guerra, así como una concepción propia de la necesidad que legitima ciertas actitudes que parecerían a otros ofensivas. Lo importante es el de poder llegar, con el concurso de la ciencia y el progreso, a un cierto acercamiento conceptual, que repercutirían en las actitudes fundamentales frente a la vida.

5. Ponente de la tercera relación fue el prof. de Filosofía del Derecho, D. Pedro Serna: "La Vita come problema di giustizia: il contributo dell'Enciclica alla civiltà del Diritto» .

Se propone mostrar las aportaciones nucleares de la EV desde el punto de vista del Derecho. Su ponencia la divide en cuatro apartados:

1. Contradicciones en la cultura de los derechos humanos.

El ponente comienza su disertación, afirmando la contradicción expresamente palpada en la EV. entre la reivindicación de la libertad, de la democracia y de los derechos humanos, por una parte, y las violaciones y amenazas contra la vida, por otra, de forma que en el ejercicio de los de- 
rechos de libertad se pretende la violación del derecho a existir de determinados grupos de seres humanos (EV. n. 13-17).

Si se niega la universalidad de los derechos, anteponiendo la libertad y el bienestar de unos sobre la vida de los otros, precisamente de los débiles, equivale a negar la igualdad y a introducir diversas categorías entre los seres humanos. Esto es lo que significa propiamente la «sociedad de excluidos», que se menciona en la Encíclica.

En nuestros días - dice- el fenómeno de la exclusión aparece en los más diversos ámbitos, como consecuencia de un pensamiento científico, político y económico disyuntivo, acostumbrado a pensar las relaciones sociales como juegos de suma cero. Es el resultado de una lógica que afecta principalmente a los que dejarán de vivir para garantizar el bienestar o la libertad de otros, pero también a quienes vivirán peor, en condiciones infrahumanas.

Este es uno de los principales problemas de nuestros días: la universalidad expansiva de los ideales modernos del progreso material y de la libertad individual, que resulta imposible de alcanzar si se mantienen las actuales características del tecnosistema que integran el Estado y el mercado.

El ponente, aludiendo al modelo económico capitalista, impotente para evitar la exclusión social, y a los ataques contra la vida llevados a cabo en nombre de la libertad, manifiesta que se introduce el criterio de la fuerza como patrón de la convivencia. Cuando, además, se pretende llevarlo mediante instrumentos jurídicos, el ordenamiento jurídico queda invadido por ese déficit de civilización. Al modo de ver del ponente se trata de una violencia refinada, situándonos en las antípodas no sólo de la justicia, sino de la misma idea de Derecho.

2. El diagnóstico de una situación: Desenfoque en la imagen de la dignidad y la libertad.

Para Juan Pablo II, pretender que la libertad humana se puede extender legítimamente hasta incluir un supuesto derecho a privar de la vida a otros seres humanos sólo se explica por una comprensión defectuosa de la dignidad de la persona humana, por una parte, y de la libertad que le es connatural, por otra (n. 19). Es preciso negar la dignidad de las víctimas y ampliar notablemente el alcance del uso legítimo de la libertad a quienes realizan la agresión.

La Encíclica señala que el concepto de dignidad personal que se requiere para ello es aquél que la identifica con la autonomía (Ib.). Otra concepción que niega la dignidad al débil prosigue el Papa, es aquella que «tiende a identificar la dignidad personal con la capacidad de comunicación verbal y explícita» y, en todo caso, experimental ( $I b$.)

Respecto al concepto de libertad, es aquél «que exalta de modo absoluto al individuo, y no lo dispone a la solidaridad, a la plena acogida y 
servicio del otro (....) una visión de la libertad muy individualista, que acaba por ser la libertad de los "más fuertes" contra los débiles destinados a sucumbir» (Ib.).

El ponente, tras esta citación del texto n.19 de la EV., dice, refiriéndose al concepto de «dignidad», que la absolutización de la autonomía no es criterio limitador ni orientador para la praxis humana. Por otra parte, quien no es autónomo queda en una posición semejante a la del universo natural, asimilado a un objeto en el espacio, donde se despliega la actividad del sujeto autónomo, que puede ser removido en el caso que obstaculice dicho despliegue. Como se señala en la EV., ello se muestra en abierta contradicción con la teoría de los derechos humanos, que «se fundamenta precisamente en la consideración del hecho que el hombre, a diferencia de los animales y las cosas, no puede ser sometido al dominio de nadie» (n.19) En consecuencia, ¿cómo conciliar esta postura con la exaltación del hombre como indisponible? (Ib.).

Ante esta denuncia implícita en esta pregunta se podría contraargumentar declarando el carácter sólo aparente de la disposición sobre el ser humano en los casos de aborto y eutanasia, por ejemplo: dicho carácter se haría visible si se considera que no se trata de sujetos propiamente humanos. El ser no autónomo no sería humano y, en consecuencia, no poseería derecho alguno. Pues bien, para el ponente, al afirmar esto es cuando se entra en colisión frontal con la teoría de los derechos humanos, pues no hay acto más fuerte de disposición sobre un ser humano que establecer si lo es o no. Caracterizar la dignidad humana en términos de autonomía, pretendiendo constituirse en criterio para determinar quién es ser humano y quién no lo es, constituye un auténtico acto de poder que viola la misma dignidad humana entendida como exigencia de no disposición, de respeto al «fin en sí mismo». Y desde aquí puede entenderse - continúa el ponente - el alcance filosófico y jurídico de la propuesta contenida en la Encíclica, en orden a considerar intrínsecamente valiosa toda vida humana.

Por análogas razones puede discutirse el segundo concepto de dignidad, que la entiende vinculada esencialmente a la capacidad de expresión, al logos verbal fácticamente poseído.

Respecto al concepto de libertad, en la EV. se pone de relieve que se trata de una libertad desnaturalizada, separada del propio hombre y de todo vínculo constitutivo con la verdad (n. 19).

Se trata de una libertad que ha dejado de ser un bien, para convertirse en un valor, que será reivindicado en y desde sí mismo y, por ello carecerá de límites y fundamento. Las consecuencias de esta desnaturalización, aludidas en la EV. (n. 20), nos lleva en el plano estrictamente personal a la amarga experiencia del existencialismo (si no hay naturaleza, cual- 
quier uso posible de libertad será correcto) y, en el plano político, a una suerte de politeísmo axiológico, que desemboca en la guerra de unos contra otros y en la imposibilidad de encontrar más criterios de armonización que la arbitrariedad resultante del juego de las fuerzas.

En el mundo del derecho se acusa también estas consecuencias. Por una parte, se establece una jerarquía entre los diferentes derechos, que no infrecuentemente oculta una jerarquización entre las personas. Por otra, se intenta el recurso a una ponderación entre los intereses en juego que fácilmente incurre en la arbitrariedad, al no disponer de referente metapositivo. El formalismo jurídico dificulta aún más las cosas, pues el criterio invocado para la valoración constitucional de las conductas es «la regla de las mayorías», olvidándose que los derechos fundamentales valen precisamente en la medida que constituyen límites al poder, ya provenga éste de las mayorías o de cualquier otra instancia. No valen en virtud del pluralismo, ni de la tolerancia, sino como límite de las expresiones legítimas de ambos.

3. En el horizonte de una crisis profunda.

El ponente apunta algunos corolarios que cabría obtener de la lectura de los nn. 21 y 22 de la EV.:

1) La desaparición del Absoluto, o su relegamiento al ámbito completamente privado, al fondo de la conciencia individual, hacen absurdo, por inviable, aspirar a una defensa del valor incondicional de la persona.

2) La ausencia del Absoluto no es originaria, sino originada por una realidad estrictamente personal, que es el alejamiento voluntario por parte del hombre. Desde este alejamiento voluntario se pierde la referencia a lo divino, y el resto del universo queda afectado por una radical indiferencia. A partir de este contexto todo queda unificado bajo la forma de no-yo, formando un horizonte uniforme, potencialmente reducido a la condición de cosa, de campo para el despliegue de la actividad del yo, sobre el que habrá de ejercitarse la afirmación de sí mismo.

3) De lo dicho se desprende que no es correcto trazar una separación completa entre el desorden moral interior y el externo. La justicia se ve amenazada cuando las demás virtudes lo están. Por ello, aunque es posible hablar de virtudes públicas, no puede señalarse ninguna que sea absolutamente privada, incluso en lo relativo a sus efectos inmediatos. $\mathrm{Si}$ bien es verdad que no toda la moral es exigible institucional y coactivamente, jurídicamente, también es verdad que la llamada ética privada sea completamente ajena a la suerte de las comunidades políticas. La relevancia política de la presencia social de la idea de lo Absoluto, por una parte, y de la moral personal de los ciudadanos, por otra, constituye otra aportación destacable de la Encíclica, cuya traducción jurídico-constitucional apunta en la dirección de una democracia no relativista, posible y 
deseable, de una comunidad política que renuncie constitucionalmente al principio de la soberanía absoluta, en beneficio de límites infranqueables por la decisión de los poderes constituidos, límites que coinciden con los derechos fundamentales.

4. La dimensión jurídica de las propuestas positivas de la Encíclica.

4.1. Un nuevo fundamento para la dignidad humana.

El fundamento del carácter de «res sacra» del hombre que se pretende postular cuando se habla de dignidad se encuentra en su relación con el Absoluto. Por eso, la idea de dignidad no tiene sentido fuera de una metafísica de la creación. Desde estas coordenadas la racionalidad del hombre se revela como el signo de una llamada del Absoluto, contenida en el propio designio creador. Esta relación desde el Absoluto nos sitúa más allá del plano puramente óntico y nos transporta a un ámbito metafísico-teológico. Según el ponente, esta fundamentación metafísica-teológica de la dignidad está insinuada en la EV. n. 2 y, a su juicio, el reconocimiento de la condición criatural de uno mismo y de los semejantes es precisamente lo que conduce a relativizar las propias pretensiones de actuación sobre naturaleza y sobre los restantes seres humanos, y a convertir a éstos en destinatarios de un respeto que no se hace depender de condiciones.

4.2. El valor de toda vida humana.

De lo anterior se desprende el valor de cada vida humana.

La vida humana no puede ser objeto de disposición, ni por parte de la comunidad política, ni tampoco por parte de sí mismo. El derecho a la vida es, propiamente un derecho inalienable. En rigor, también serán inalienables todos los derechos pertenecientes a la categoría de los derechos humanos. La regla de la inalienabilidad sólo admite la excepción de la legítima defensa, tema - dice- del que no puede ocuparse.

Ese carácter no disponible, fruto de la exigencia de respeto derivada de la dignidad, obliga al ordenamiento jurídico a abstenerse de fijar cualquier criterio convencional sobre el comienzo del derecho a la vida. Ello no obsta que en el ámbito estrictamente patrimonial se mantengan antiguas reglas jurídicas que vinculan el comienzo de la personalidad con el hecho de nacimiento.

Finalmente, el derecho a la vida reclama del ordenamiento la máxima protección. La despenalización no es el camino para conseguir este objetivo, además de contribuir a difundir una relativización del valor de la vida. Según el ponente la Teoría contemporánea del Delito dispone de los recursos suficientes para resolver con justicia la causa de aquellas mujeres, cuya responsabilidad criminal se haya atenuada en virtud de las circunstancias que la llevan a someterse a un aborto voluntario. 


\subsection{Libertad y naturaleza.}

La libertad política y jurídica se despliega en un conjunto de libertades, cuya medida depende de un ajuste dinámico y encuentra su principal criterio de limitación interna y de armonización con las libertades y derechos de los demás en un «contenido esencial» definido a partir del fin de cada derecho.

Si se introduce la idea de naturaleza humana en el tratamiento de la libertad, ésta se encontrará esencialmente abierta a la verdad y limitada por ella, tanto en su dimensión personal como en su despliegue político y social, como se sugiere en la EV.

6. En el debate se le cuestiona al ponente, que parece seguir la escuela de Hervada, sobre el concepto de «personalidad». ¿Dónde está el personalismo? Todo ser humano es persona en el plano ontológico y, por lo tanto, lo es en lo jurídico.

R.-En mi exposición hablo de los deberes («no matarás»), que tienen su origen en la persona.

Se hace alusión a la pena capital: Si el derecho es expresión del valor de la persona. Si el derecho se enraiza en la libertad, ¿cómo puede justificarse la pena capital?

Se dice que la cultura laica cae en contradicción, pues, por una parte desprecia el inicio de la vida humana y, por otra, es contraria a la pena capital

R.-Existe dicha contradicción originada por la ausencia del Absoluto, que permite la desaparición del no nacido.

Respecto a la pena capital, me atengo al Catecismo de la Iglesia Católica, por lo que sólo es posible en la legítima defensa.

Varias voces se alzan oponiéndose a la pena capital, pues el delincuente tiene un derecho como persona, sin merma de su dignidad. Además, no se ve que hoy existan casos de absoluta necesidad, que legitimen la pena capital.

Otra de las preguntas hace referencia al espíritu kantiano acerca de la dignidad humana. Según el ponente, fuera de la teología no hay respuesta. Cree el interpelante que partir de la teología es partir desde una opción particular.

R.-La experiencia alemana muestra la pérdida del Absoluto. Desde la concepción kantiana no se justifica el «fin en sí mismo».

7. Se da lectura a dos comunicaciones. Una hace referencia al Riesgo discriminatorio y selectivo en ingeniería genética y procreación artificial y la siguiente a la Objeción de conciencia.

El ponente de la primera comunicación es el Dr. W.M.O. Moore, Asesor de Obstetricia de Bupa Medico-Legal Services. Presidente del Linacre Centre For Healthcare Ethics. 
El ponente pretende informar sobre el diagnóstico genético llevado a cabo con prácticas clínicas asociadas a la procreación artificial. Si bien, el conocimiento genético, como todo conocimiento, puede ser mal empleado, también puede aportar grandes beneficios a la sociedad. El desafío consiste en asegurar que la humanidad goce de sus beneficios y rechace sus abusos.

Manifiesta desde el comienzo que lo que va a exponer es contrario al magisterio de la Iglesia. Aparte del hecho que las técnicas de reproducción artificial son moralmente inaceptables, desde el momento que separan la procreación del contexto plenamente humano del acto conyugal, el número de embriones producidos es frecuentemente mayor que los que hacen falta para la implantación en el útero de la mujer. Además, algunos embriones se someten a pruebas que no van dirigidas a mejorar sus condiciones de salud o su supervivencia individual.

Plantea el sufrimiento de las parejas con riesgo de tener un hijo con una enfermedad genética. En la actualidad, en el mundo occidental - dice-, si una pareja quiere tener un hijo con estas perspectivas, tiene las siguientes opciones: $1 .^{\circ}$ Evitar concebir un hijo; $2 .^{\circ}$ Adoptar un niño; $3 .^{\circ}$ Correr el riesgo y esperar que el hijo que conciban no esté afectado por la enfermedad; $4 .^{\circ}$ Hacer pruebas al feto durante la gestación y considerar la opción del aborto.

En un futuro cercano las parejas tendrán una opción más, porque después de muchos experimentos con embriones humanos producidos por fecundación in vitro (en adelante IVF = «in vitro fertilisation») la posibilidad de escoger embriones libres de cualquier enfermedad genética particular se ha convertido en una realidad.

Acto seguido expone las razones de esta opción.

Cuando la fecundación se realiza naturalmente in vivo, el espermatozoide y el óvulo se encuentran y se unen en la trompa de Falopio (oviducto). En los días siguientes el embrión crece y baja de la trompa de Falopio para alcanzar el útero, donde queda implantado cinco o seis días más tarde.

En la IVF se emplea el mismo esquema temporal: el embrión formado en tubo de ensayo es trasladado por vía vaginal al útero seis días más tarde. De este modo la unión de IVF con la nueva genética molecular ofrece la oportunidad de un diagnóstico genético antes de la implantación.

La experiencia fiable del diagnóstico previo a la implantación (en adelante PID = pre-implantación diagnosis) está basado en los programas de IVF, pues proporcionan un esquema de trabajo clínicamente muy apropiado.

La práctica actual del PID implica lo siguiente: 
1. Quitar una sola célula de un embrión de 4 células, o 2 células de un embrión de 8 células, a los dos días, o

2. Biopsia de la trofectoderma (capa de células destinadas a convertirse en placenta) de un embrión de 5 días, que contiene unas 200 células.

La técnica es extremadamente sencilla. Las células separadas por la biopsia son sometidas a distintas pruebas, según la anomalía que se intenta detectar. Es práctico tener la respuesta el mismo día, de modo que los embriones seleccionados puedan ser llevados al útero no más tarde de lo que serían en un tratamiento rutinario de IVF.

Sorprendentemente, no hay muestras que la biopsia del embrión comprometa su posterior desarrollo ni que reduzca la tasa de gestaciones que llegan a buen término después de la implantación. Si el embrión sufriera daño durante el proceso de la biopsia, el resultado sería su no implantación (muerte del embrión) y no, por lo tanto, anomalías estructurales en el parto.

Los estudios más recientes indican que la biopsia de una cuarta parte de la masa celular del embrión a los tres días es el momento óptimo para la fiabilidad del análisis genético y el posterior desarrollo del concebido.

Sería muy engañoso dar la impresión de que el PID es sencillo de llevarse a cabo y libre de error. Ya ha habido errores. En el Reino Unido uno de cada siete fetos procedentes de embriones diagnosticados como hembras y exentos de anomalías genéticas específicas resultaron ser varones, cuando se les sometió a pruebas más tarde en la gestación. Las parejas decidieron terminar la gestación mediante aborto. En los Estados Unidos uno de cada cinco embarazos comprobados, iniciados supuestamente con embriones exentos de anomalía genética específica demostró ser un feto homocigoto en relación con la fibrosis quística.

Los errores se debieron probablemente a la aplicación de nuevos métodos, antes de haberse demostrado que eran suficientemente fiables. Harán falta muchas pruebas con embriones humanos para estar seguros de que el análisis genético es inequívocamente preciso y de que el nivel de riesgo que implica todo el proceso es bajo.

De las más de 4.000 anomalías genéticas conocidas, algunas son más comunes que otras. En conjunto, alrededor de un uno por cien de niños que nacen vivos están afectados por una enfermedad genética seria. Hasta ahora el PID se ha realizado en embriones humanos obtenidos por IVF de pacientes afectados de fibrosis quística, enfermedad de Huntington, distrofia muscular de Duchenne y un puñado de raros defectos de un solo gene. Solamente las más graves anomalías de un solo gene son las candidatas para el PID en este momento.

Si el defecto genético es recesivo y ambos progenitores poseen el mismo defecto recesivo de un solo gene, transmitirán la enfermedad, por 
término medio, a uno de cada cuatro de sus hijos. Ejemplo: la fibrosis quística, que afecta a uno de cada 2.000 nacimientos en el Reino Unido. Se trata de una enfermedad pulmonar crónica y, a la larga, fatal.

Si el defecto genético que está en uno de los progenitores es dominante, la mitad de los hijos, por témino medio, de esa pareja heredarán el gene. Ejemplo: la enfermedad de Huntington, que afecta a uno de cada 10.000 nacimientos en el Reino Unido; el $99 \%$ de los niños que heredan este gene eventualmente desarrollan un estado caracterizado por una incapacidad progresiva y sin remisiones que, finalmente, conduce a una demencia precoz.

Si el defecto genético está en uno de los crosomas sexuales de los padres (cromosoma X), afecta solamente a los hijos del mismo sexo. Ejemplo: la atrofia muscular de Duchenne, que afecta a 1 de 4.000 varones (son raros los casos en los que las afectadas sean mujeres) en el Reino Unido; la enfermedad se caracteriza por una progresiva degeneración muscular y un debilitamiento que lleva a la muerte por fallo del corazón.

La demanda del PID crecerá inevitablemente, porque ofrece a las parejas, que tienen alto riesgo de trasmitir una enfermedad genética, la oportunidad de un diagnóstico antes que comience en el útero la gestación. La disponibilidad simultánea de varios embriones procedentes de la IVF hace posible descubrir embriones exentos de defectos genéticos específicos para implantarlos en el útero.

Lo que está teniendo lugar es una revolución ética, que trasciende los límites de cualquier país. En estos momentos no existe en Europa un consenso, en cuanto el uso de la IVF para el PID. En el Reino Unido está regulado por la «Human Fertility and Embryology Authority», la cual prohíbe la manipulación de la estructura genética del embrión, los intentos de clonación, la mezcla de células humanas y de animales en el desarrollo del embrión, y en el uso de las técnicas que permiten a las parejas escoger el sexo de sus hijos, excepto en los casos de enfermedades vinculadas al cromosoma X. En Francia puede decirse que la legislación inicial, que declaraba ilegal el PID se va suavizando en los casos graves de enfermedades hereditarias. En Alemania está totalmente prohibido. Mi opinión es que muchas de las restricciones actuales serán eliminadas en los próximos años.

Alude a la Comisión Europea, que ha establecido un Comité de representantes de cada Estado miembro para examinar las consecuencias éticas, legales y sociales de los programas de las ciencias de la vida en su Framework Programme for Researh and Development. Este Comité asegurará que haya una efectiva coordinación entre los programas y que las actividades se ajusten a las regulaciones que sean necesarias. 
La segunda comunicación del prof. de Derecho Eclesiástico en la Facultad de Derecho en la Universidad de Turín, Dr. Vicenzo Turchi, referente a la objeción de conciencia, da inicio, afirmando que la objeción de conciencia, entendida como derecho subjetivo connatural a la persona parezca, a primera vista, como una adquisición relativamente reciente por parte del magisterio de la Iglesia, las fuentes históricas y teológicas del magisterio al respecto son antiquísimas y radicadas tanto en la Escritura como en la Tradición, sobre todo, a partir de la revelación neotestamentaria, donde la conciencia informada por el espíritu de la Ley Nueva, perentoriamente, reclama «oportet oboedire Deo magis quam hominibus».

Haciendo un breve recorrido de la historia sucesiva de la Iglesia, desde las persecuciones de los primeros siglos hasta Sto. Tomás Moro, testigo de la verdad del derecho contra la injusticia de un imperativo legal, y, citando a Gelasio I, a Inocencio III, S. Buenaventura, Sto. Tomás de Aquino, en cuyos textos se reconoce el valor primario de la conciencia, se detiene, como punto de reflexión crítica e investigación cultural, en la nota pastoral de la Conferencia Episcopal Italiana, «Educare alla legalità», del 4 de octubre 1991. En un contexto general, dedicado a la necesidad de desarrollar «una renovada cultura de la norma», de educar «por un sentido más maduro de la legalidad», se declara — dice— la objeción de conciencia, como «algo de extrema seriedad», en cuanto se «conecta a una precisa antropología personalista, rechaza toda concepción totalitaria del Estado, apunta decisivamente sobre la íntima conexión entre legalidad y moralidad»; la objeción de conciencia se enraíza no en la autonomía absoluta del sujeto respecto a la norma y, mucho menos, en el desprecio de la ley del Estado, sino en la coherente fidelidad al fundamento de la ley civil. La objeción de conciencia, de hecho, frente a una ley del Estado, atestigua el valor primario de la persona y de su justa libertad; es deber del Estado democrático el de no imponer una adhesión incondicional a las normas establecidas por la autoridad, sino el de dejar al ciudadano «la posibilidad de reflexionar libremente sobre la realidad legislativa del momento, y así preparar, llegado el caso, una eventual reforma de la legislación».

Siguiendo la nota pastoral, el ponente se centra en la objeción de conciencia ante el aborto, dejando aparcada la objeción de conciencia referente al servicio militar.

El mandamiento de no matar a un inocente obliga moralmente, de forma grave, a todos y siempre. La «cultura de la vida» representa la base, por así decirlo, material, de la objeción de conciencia, la cual, a su vez, encuentra su propia raíz, como se ha visto, en las mismas fuentes bíblicas, Tradición y en el «sentir y consentir» de todo el pueblo de Dios. 
En realidad, no existe valor más humano que el de la vida. Por ello, cuando la Iglesia interviene en defensa de la vida, desde la concepción a su muerte natural, la Iglesia no quiere introducir un Estado cristiano: «quiere simplemente promover un Estado humano. Un Estado que reconozca como su deber primario la defensa de los derechos fundamentales de la persona humana, especialmente de la más débil» (VE. n. 101).

Al juicio del ponente, las varias hipótesis de objeción de conciencia deducibles del EV., pueden reconducirse en conjunto a la categoría general de la objeción de conciencia en el campo bioético. Dentro de este campo, pueden especificarse los distintos casos en los que cabe plantear la objeción de conciencia: la objeción al aborto, a la eutanasia, a las manipulaciones genéticas, sobre todo, a las que conllevan el resultado letal del embrión, y, finalmente, las objeciones que pueden nacer en aquella rama de la bioética, que es definida procreativa; precisando que en este último caso sólo se atenta al principio del respeto de la vida humana, en modo directo e inmediato, cuando a las susodichas técnicas de fecundación artificial les acompaña la supresión de los embriones. Si así no fueran, el principio ético que viene en consideración no es el del derecho a la vida en sí, sino el principio, ciertamente importante, pero probablemente de menor obligación moral, de la dignidad y del significado unitivo del acto procreativo humano.

En cuanto al aborto, dada por supuesta la doctrina de la Iglesia, el ponente pone su acento, por una parte, en algunos particulares sujetos, a quienes se les debiera reconocer el derecho a la objeción y, por otra, en la individualización de las específicas fases, objeto de la objeción misma.

Junto a los sujetos, por así decirlo tradicionales y típicos, a saber, el personal médico y sanitario, se reclama la situación particular del juez tutelar que en el ejercicio de sus funciones deba autorizar el aborto del menor: La Corte constitucional italiana, con sentencia n. 196 del 1987, ha considerado infundada la cuestión de la legitimidad de la ley sobre la interrupción voluntaria del embarazo, en cuanto no se prevé la objeción de conciencia en dicha circunstancia. El Episcopado italiano, por su parte ha manifestado inmediatamente la necesidad de legitimar, también, este tipo de objeción.

Se recuerda la situación de los farmacéuticos en los países en los que está legalizada la venta de la así dicha píldora abortiva, la R.U. 486, en el caso que no estén a salvo, en el ejercicio de su profesión, por alguna cláusula de conciencia.

Respecto a los perfiles objetivos, la EV. pide que la objeción de conciencia sea tenida en cuenta en la fase consultiva, preparatoria y ejecutiva del procedimiento abortivo (n. 74). 
En este apartado el ponente quiere hacer constar que la objeción de conciencia no significa que el objetor deba abstenerse de ofrecer, en la fase consultiva, formas disuasorias del aborto en pro de la maternidad. A su juicio, es un deber para el médico objetor hacer uso de todas las posibilidades ofrecidas por la ley en pro de la vida, y una injusticia si la legislación civil no admitiera la intervención del médico objetor en esta función promocional en favor de la vida.

Siempre en referencia a estos perfiles objetivos, la objeción de conciencia debe tenerse presente también en las prácticas del diagnóstico prenatal, si están funcionalmente conexas al aborto (aborto selectivo). De igual forma, en las manipulaciones genéticas, a no ser que su objetivo sea estrictamente terapéutico. En particular, la hipótesis de la occisión del embrión fecundado in vitro, no implantado en el útero, pero capaz de vivir y aún de alojarse. Se trata de casos en los que, aun en la ausencia de una disposición, es legalmente, no sólo moralmente, lícito plantear la objeción de conciencia, por lo menos, en virtud de una extensión análoga de las normas referentes al aborto.

No parece que exija particulares reflexiones el tema de la objeción de conciencia frente a la eutanasia, en el supuesto de su legalización. Los mismos principios sobre el valor de la vida y sobre el sentido de la vida humana son aplicables en el caso.

En fin, el objetor, en los posibles casos descritos, debe estar a salvo tanto en el ámbito penal como en el plano legal, disciplinar, económico y profesional.

Queda un último problema: los principios éticos de las diversas formas de procreación asistida.

El lugar propio de la generación es el amor conyugal, consagrado por y en el matrimonio. En consecuencia, la fecundación heteróloga contrasta con la propiedad de la unidad del matrimonio, con la naturaleza propia de la familia, según la tradición hebrea-cristiana. De ahí, el deber de plantear la objeción de conciencia por parte del agente sanitario parece coherente, puntualizando que esta obligación no posee la misma entidad, en el ámbito moral, que la planteada respecto a la inviolabilidad de la vida.

Tocante a la fecundación homóloga, si bien no atenta a la unidad del matrimonio, queda la disociación del significado unitivo del acto conyugal con el procreativo, razón por la que, según la doctrina de la Iglesia, es moralmente ilícita.

Como conclusión de estas reflexiones, el ponente quiere recalcar que el derecho-deber de la objeción, sin más, no representa ciertamente la solución de los problemas que emergen en el campo de la bióetica. Representa un «no» que se impone como imperativo categórico a la concien- 
cia, «el límite infranqueable más allá del cual el hombre libre no puede pasar y, al mismo tiempo, indica el mínimo que debe respetar y del que debe partir, para pronunciar innumerables "síes"» (EV. n. 75).

8. Tras estas comunicaciones vino el espacio dedicado al debate. En realidad, el tiempo se agotó redundando en el temario expuesto. Se alude al veto del Presidente de USA, Sr. Clinton, a la ley del Parlamento, prohibiendo el aborto a las 20 semanas $^{5}$. Se explica el modo de proceder: se saca el feto del útero de la madre, se introduce una aguja en el cráneo, provocando la muerte instantánea. Lo espantoso del caso —manifiesta un doctor ginecólogo americano- es afirmar que esta intervención no deja secuelas en la madre, cuando, en realidad, produce una infección en la placenta, dejando a la madre afectada para siempre.

9. El segundo día del congreso se abrió con la conferencia de la prof. de la facultad de Derecho en la Universidad de Harvard, Doña Mary Ann Glendon: Identità della donna e diritto alla Vita.

La ponencia consta de cuatro apartados:

1. Tiempo de turbulencia.

Como hace tiempo recordaba S. Pablo a los Corintios, una ley que nunca puede ser revocada es la ley del cambio: «Pasa la apariencia de este mundo». Pero mientras el cambio es una constante, su ritmo es variable.

Nuestro tiempo se caracteriza por una transformación social tan rápida que, a menudo, nos sentimos desorientados Las estructuras intermedias de la sociedad civil, incluida la familia, parece que están en desorden. Criterios que han regulado durante mucho tiempo los comportamientos de hombres y mujeres están siendo cuestionados. Y, citando el n. 4 de la EV., destaca tres rasgos de este tiempo de cambios que nos ha tocado vivir, que los considera importantes para el tema de su conferencia:

1) Este tiempo de turbulencia ha dado lugar a una serie de situaciones sin precedentes en la historia.

2) Ha sido el período en que el feminismo moderno ha tomado forma de movimiento organizado.

3) Es sorprendente cómo muchos de los cambios más profundos y de los dilemas de nuestro tiempo han ido enlazados con una transformación de los roles de la mujer.

La ponente concreta más este último rasgo:

5 OR., 13 de abril, 1996, 2; Respuesta de la Conferencia Episcopal de USA, en OR., 19 de abril, 1996,4. 
a) La mujer, en los países desarrollados, ha hecho grandes avances en educación y trabajo. El cambio más dramático en ese campo ha sido que las madres de niños pequeños han entrado de una manera masiva en el mercado del trabajo remunerado. Mas hay que tener en cuenta que tan importante como lo que cambia es lo que no cambia: mientras el grupo tradicional de la sociedad que prestaba cuidados sin remuneración ha disminuido, la proporción de personas que no pueden valerse por sí mismas — niños, enfermos, incapacitados- permanece inalterable, y la sociedad no ha encontrado todavía solución a este problema.

b) El impacto del divorcio no es el mismo en el hombre que en la mujer. La relación divorcio-riesgo de pobreza es mayor en las mujeres que quedan con sus hijos, como cabezas de familia. Esto ha traído como consecuencia que las mujeres tienen menos hijos.

c) La vida de la mujer ha sido profundamente afectada por el debilitamiento de la conexión entre sexo y procreación. El aborto no sólo se ha hecho realmente admisible, sino que ha encontrado diversos grados de legitimación. La biotecnología ha transformado el proceso de la reproducción humana con contraceptivos hormonales, inseminación artificial y fecundación in vitro.

Estos cambios han tenido su reflejo en la legislación de las democracias liberales. A partir de 1960, leyes, que habían permanecido inalterables durante más de una centuria, han sufrido un cambio radical. El matrimonio, que era una institución, cuyo término legal era sólo por la muerte o por una causa grave, ha pasado a convertirse en un acuerdo, que puede deshacerse a instancia de uno de los cónyuges.

Una serie de leyes y programas se han estructurado de tal manera que el foco de su atención va dirigido al individuo más bien que a la familia como tal, con lo que se enfatiza la separación de los miembros de la familia, en lugar de promover su unión.

Las leyes han reducido ampliamente su desaprobación de las relaciones sexuales, fuera del matrimonio, entre adultos.

El aborto no sólo ha llegado a ser permitido en ciertas circunstancias, sino que en USA, por decisión judicial, ha sido elevado al rango de derecho constitucional de la mujer. En las recientes conferencias de la ONU en El Cairo (1994) y en Beijing (1995) se hicieron esfuerzos por lograr el reconocimiento del aborto como derecho universal humano.

A juicio de la ponente, como considera previsible que iniciativas legales de este tipo continúen a nivel nacional e internacional, le parece muy oportuno dedicar atención al problema de la enorme diferencia de sentido que dan a palabras como «derechos» $\mathrm{o}$ «libertad» quienes toman parte en los debates políticos. 
2. Los dos lenguajes de los Derechos.

Mary Ann habla de la experiencia que hemos tenido todos, cuando hemos comenzado a aprender un idioma distinto al nuestro. Nos encontramos con la agradable sorpresa de palabras afines a las de nuestro idioma. Pero, muy pronto, descubrimos lo que los franceses llaman «faux amis», falsos amigos, palabras que tienen el mismo sonido que las de nuestro idioma, mas tienen un significado completamente distinto.

La ponente traslada esta experiencia, a lo que sucede en los debates sobre los derechos humanos. Según ella, «la reciente conferencia de Beijing fue un ruidoso bazar, donde abundaron los malentendidos lingüísticos». Califica de siniestro «el caballo verbal de Troya, que vino a ser una especie de mantra para la conferencia de Beijing»: «Los derechos de la mujer son derechos humanos y los derechos humanos son derechos de la mujer». Este slogan es verdadero a medias. Los derechos humanos son derechos de la mujer y del hombre, basados en la dignidad humana, afirmación expresa en la Declaración Universal de los Derechos humanos de 1948. Pero la afirmación inversa que «los derechos de la mujer son derechos humanos» fue un intento de introducir como de contrabando en el elenco internacional de los derechos humanos varios «derechos reproductivos», que han sido reconocidos como derechos de la mujer en unos pocos Estados.

Lo que hay que poner de relieve aquí - dice- es que los debates más recientes sobre los derechos no versan simplemente sobre lo que debería reconocerse o no como derecho. En el fondo, versan sobre el sentido mismo de lo que es tener un derecho, sobre la estructura y sentido de la libertad, en particular, sobre la relación entre libertad y responsabilidad y verdad y, en última instancia, sobre la naturaleza de la persona humana.

Palabras como «derechos» 0 «libertad» tiene muy diferentes significados dentro de las dos principales formas del discurso político en el mundo actual. La ponente califica estos dos lenguajes con unos adjetivos que no tienen traducción literal al español: «libertariam language» y «dignitariam language», es decir, — parafraseamos nosotros- un lenguaje basado en un concepto de la libertad como ejercicio de una autodecisión sin restricciones e individualista y un lenguaje basado en la dignidad de la persona humana que exige la solidaridad con los demás.

Ya en el siglo XVIII podían advertirse divergencias en el horizonte común del pensamiento moderno sobre los derechos. La tradición política angloamericana ha promovido las libertades políticas y civiles, configurándolas como «derechos negativos», a saber, como una no intervención del Gobierno; mientras que los países más influidos por la tradición romano-germánica han hecho que esos derechos políticos y civiles vayan 
acompañados de ciertas obligaciones positivas por parte de los Estados respecto de los ciudadanos y por parte de los ciudadanos respecto unos de otros.

Esta diferencia se ha acentuado en nuestros días. El discurso sobre los derechos en los países de influencia anglo-americana concede la máxima prioridad a la libertad del individuo frente a las restricciones por parte del Gobierno. En estos sistemas se tiende a formular los derechos sin mencionar sus límites, su relación con las responsabilidades o con otros derechos. Es notable la ausencia de derechos (o deberes) económicos y sociales del tipo de los que se encuentran frecuentemente en las Constituciones de la Europa continental.

El discurso «dignitario» sobre los derechos, que encontramos en la Declaración Universal de los Derechos Humanos de 1948, en algunas Constituciones posteriores a la Segunda Guerra Mundial y en la doctrina social de la Iglesia católica se caracteriza por un tratamiento más matizado de la libertad y de la responsabilidad. Los derechos son vistos, no sólo como protegidos por unos procedimientos justos, sino también como dotados de una estructura normativa, basada en el respeto a la dignidad humana. Los derechos específicos se formulan de tal manera que queda clara la relación de unos con otros, que ciertos grupos tienen derechos como los individuos y que las entidades políticas tienen responsabilidad como los ciudadanos.

Así, incluso en documentos profanos, la libertad ligada a la dignidad del hombre («dignitariam freedon») apunta hacia la idea central acerca de la libertad humana expresada en la «Veritatis Splendor» y en la «Evangelium Vitae», a saber, que la auténtica libertad no puede estar desconectada de la verdad.

3. Derechos de la mujer y libertad auténtica.

El feminismo duro de los años 70 no ha conseguido la adhesión mayoritaria de las mujeres, ni en Estados Unidos, donde tienen influyentes portavoces.

Llama la atención, sobre todo, el que las mujeres jóvenes estén más alejadas del feminismo «oficial» que las mujeres mayores. Las encuestas americanas revelan que solamente una de cada cinco mujeres, que están estudiando, se considere feminista.

La razón principal, por la que las mujeres de hoy rechazan la etiqueta de «feminismo», según un reciente estudio, realizado por la historiadora Elizabeth Fox-Genovese, es que identifican ese término con un movimiento y con unas organizaciones, que son percibidas por ellas como indiferentes a sus preocupaciones más profundas.

Más en concreto: no lo admiten por la actitud negativa del feminismo oficial hacia el matrimonio y la maternidad, por su actitud antagónica 
respecto a los hombres, por su intolerancia a que se pueda disentir de su toma de posición en temas como el aborto o la homosexualidad.

Como dice el feminismo libertario extremista, no parece ilusorio esperar la aparición de un nuevo feminismo, que opte por la afirmación de la vida. Pero surge una pregunta: ¿Cuáles serían las señas de identidad de un feminismo que promoviera una civilización de vida, así como la libertad y la dignidad de la mujer?

La ponente sugiere cuatro notas que, en su opinión, debería tener ese nuevo feminismo:

a) Escuchar a las mujeres, como advierte Juan Pablo II, cuando hablen acerca de lo que es más importante para ellas y no decirles arrogantemente lo que deberían o no deberían pedir. Cuando Elizabeth FoxGenovese entrevistó a mujeres de toda clase social y de todas las edades, encontró un cuadro mucho más complejo que el pintado por el feminismo oficial. Descubrió que la mayoría de las mujeres, independientemente de que tuviesen o no hijos, sentían una relación especial con la vida. Descubrió, también, que la mayoría de las mujeres, que eran madres, tendían a considerar la maternidad como el hecho central de su vida.

Al mismo tiempo, sin embargo, se encontró con que la mayoría de las madres deseaban ejercitar al máximo los talentos que Dios les había dado en amplias esferas, como la económica, social, política y cultural.

b) Al tratar de los problemas de la mujer como problemas sociales de gran complejidad, parece prudente tener presente en la mente, como lo ha hecho el Santo Padre, la extensión limitada de nuestro conocimiento respecto a lo que es innato y lo que es cultural en el hombre.

La ponente hace mención de cinco posturas dogmáticas, que han arrojado más sombra que luz en los problemas de la mujer:

1) El «feminismo-igualdad», que insiste en que no hay diferencias significativas entre el hombre y la mujer;

2) $\mathrm{El}$ «feminismo-diferencia», que trata al hombre y a la mujer como si fuesen virtualmente especies diferentes;

3) El «feminismo-dominancia», que proclama la superioridad de la mujer;

4) El «feminismo-género», que considera al «macho»y a la «hembra» como meros constructos de la sociedad;

5) El determinismo biológico rígido, asociado con algunos críticos del feminismo, que desearían encerrar al hombre y a la mujer en los roles que tuvieron en una imaginaria edad de oro.

c) Un auténtico feminismo no debería ser excluyente, sino que debería tratar a hombres y mujeres como compañeros, como «partners» y no como antagonistas. 
d) Un feminismo que fuera de verdad afirmador de la vida debería ser una feminismo radical. Radical en el sentido de ir a la raíz de las cosas, radical en el sentido del Concilio Vaticano II, que expone con tanto calor la idea de que los órdenes político, social y económico deben extender sus beneficios de la cultura a todos y ayudar a los individuos, hombres y mujeres, a que desarrollen sus talentos de acuerdo con su dignidad innata.

4. Mujer y civilización de vida.

La ponente, remitiéndose a la Carta Apostólica sobre la Mujer de Juan Pablo II, en la que se afirma que la mujer tiene unas dotes especiales, un «genio femenino» que el mundo necesita más que nunca (n. 4), y, rememorando el pasado, en el que las mujeres han preservado la cultura de la vida, a pesar de las dificultades de todo tipo, manifiesta que, si hoy miramos a nuestro alrededor, veremos un coraje similar en las mujeres que están sacando adelante a la familia en condiciones de enormes dificultades e inseguridad. La generación actual de mujeres tiene su propia frontera: el territorio desconocido, creado por dos décadas de cambios drásticos en el comportamiento social y político.

Sin duda, el desafío es enorme. Como se dice en la EV. la opción de defender y promover la vida puede ser tan exigente que, en ocasiones, alcanza la cota del heroísmo (n. 11). Pero ¿no es parte del secreto del radiante influjo de Juan Pablo II en el mundo de hoy, el que hombres y mujeres $-\mathrm{y}$, sobre todo, gente joven- deseen ser llamados a hacer cosas difíciles?

Como Moisés en la antigüedad, el Papa nos recuerda que no debemos tener miedo «pues el Señor tu Dios va contigo; El no te dejará ni te abandonará» ${ }^{6}$.

10. Tras esta ponencia, se alzan algunas voces interpelando a la ponente sobre el modo de poder llegar al convencimiento de nuestra sociedad. La prof. Glendon manifiesta la necesidad de presentar nuestra verdad al mundo como un proyecto a realizar por la vía del diálogo, en el que se plasme la armonía entre la Fe y la Cultura. Se alude a la carta de los Derechos de Familia, redactada al margen de la fe, del matrimonio, no como sacramento, sino como patrimonio de la humanidad. Se echa en falta el desacuerdo respecto a elementos comunes, v.g. ¿qué es el hombre, qué es la mujer?, etc.

11. La sesión matinal quedó interrumpida por la audiencia del Santo Padre concedida a los congresistas. A la tarde, se dio lectura a las dos comunicaciones matinales programadas, postergando la siguiente ponencia y comunicación p.m. al sábado a.m.

6 OR., 26 de mayo 1996, 7. 
La primera comunicación, titulada «Diritto alla Vita e diritto all'ambiente» fue leída por el prof. de Filosofía de Derecho en la Universidad de Valencia, Jesús Ballesteros.

El prof. Ballesteros divide en tres apartados:

1. La conjura contra la vida.

Se hace alusión a la EV., en la que se señala las dos posiciones antagónicas que amenazan el derecho a la vida: «una libertad sin ley» y una «ley sin libertad» (n. 22). Ambas posturas vienen a coincidir en el miedo a la vida y al futuro al asumir las premisas malthusianas del crecimiento de la población en progresión geométrica y de los alimentos sólo en progresión aritmética.

2. El derecho al medio ambiente en la doctrina de la Iglesia y en las declaraciones internacionales.

a) Antropocentrismo:

El relator, frente al ecologismo radical, se remite a la EV., en la que se afirma el dominio sobre la totalidad de la naturaleza concedido por Dios al hombre (n. 42). Por ello, tanto en el Documento del Pontificio Consejo para la Familia publicado con ocasión de la Conferencia de El Cairo (Evoluciones demográficas. Dimensiones éticas y pastorales, 25.3.94), como en las anteriores Declaraciones de Estocolmo del 72 y Río del 92, se insiste que el titular único del derecho al medio ambiente es el ser humano. En esta línea tenemos, también, la Declaración del Consejo Económico y Social de Naciones Unidas de junio del 94.

La FAO, por su parte, con motivo de la conferencia de El Cairo, destacó la exigencia de un «desarrollo más antropocéntrico habida cuenta de que los planteamientos biocéntricos no responden a las expectativas y a los recursos de los agricultores de los países del Sur. Ello evidencia la conexión entre antropocentrismo y solidaridad con los pueblos del Sur.

b) El principio de duración y la reciprocidad de los derechos y deberes. Contra el instanteísmo.

Mas al mismo tiempo que se rechaza el reduccionismo biologista, la EV., recogiendo enseñanzas de la «Sollicitudo rei socialis» se opone con igual contundencia al utilitarismo y hedonismo (n. 42). Según el relator, las reflexiones de los teóricos del derecho ambiental coinciden con las enseñanzas de la Iglesia, en las que se afirma los efectos destructivos de la autarquía, al creer que el ejercicio de su voluntad libre carece de límites y en el hedonismo, responsable de la ruina ecológica por su reducción de la atención al instante presente. Y la dimensión fundamental constitutiva del derecho al medio ambiente es precisamente la dimensión de la temporalidad, ya que «si sólo se consideran las necesidades del presente, todo recurso podría ser agotado y destruido para la satisfacción de tales necesidades y la protección carecería de sentido». La protección de los 
derechos de las futuras generaciones es el fundamento de todo el derecho ambiental. Esta protección se señala en el principio 1 de la Declaración de Estocolmo, en el principio 2 de la Declaración de Río, en el punto 1 y 2 de la Declaración de La Laguna de 26.2.94. Por consiguiente, se prohíben los actos que pongan en peligro tal conservación o el patrimonio genético o el genoma humano. Esta sería la especial novedad del derecho al medio ambiente como derecho, su condición de derecho-deber, su conciencia de la insuficiencia de la dimensión de la pretensión, sin la correspondiente responsabilidad.

c) El principio de solidaridad y la responsabilidad diferenciada de los países del Norte.

El relator, citando diversos documentos del magisterio pontificio, como «Tertio Milennio Adveniente» (n. 13), «Sollicitudo rei socialis» (nn. 37 y 28) «Laborem exercens» (n. 2) y «Evangelium vitae» (n. 5) dice que el derecho al medio ambiente exige el principio de solidaridad planetaria. Este principio cuestiona el estilo de vida dominante hoy, basado en el individualismo, ya que resulta evidente que el individuo aislado se encuentra impotente para hacer frente a los desafíos ambientales.

La conciencia de esta solidaridad planetaria se recoge en la Carta de Río en su n. 7, donde se subraya la mayor responsabilidad de los países del Norte en relación con los del Sur en el mantenimiento del desarrollo duradero, debido a la presión mucho más elevada que su modelo de producción y consumo ejercita sobre el ambiente mundial. La principal causa de los desequilibrios ecológicos se debe al uso abusivo por parte del Norte de recursos no renovables e indispensables para la continuidad de la especie, así como la acumulación de armas capaces de destruir varias veces el planeta.

3. El derecho a la vida y el derecho al medio ambiente.

Frente a las dos actitudes amenazantes del derecho a la vida, la Doctrina social de la Iglesia y las Declaraciones Internacionales coinciden:

A) Considerar al ser humano como titular único de derechos, frente a los biologismos. Si bien este derecho aparece claramente unido al deber de cuidar de los recursos.

B) Defender a las futuras generaciones como titulares de derechos, frente a las tesis malthusiana, que reduciría los derechos a los titulares actuales del derecho de propiedad.

C) Subrayar la responsabilidad fundamental del Norte en la generación de los desastres ecológicos, debido a su mucha mayor presión sobre el ambiente.

La segunda comunicación del prof. Hugo Obiglio, miembro de la Pont. Academia para la Vida, Director del Instituto de Etica Biomédica 
de la Pont. Univ. Católica Argentina, lleva como título: «Sperimentazione sull'uomo e diritto».

El relator comienza la lectura de su disertación, manifestando que se impone romper la sinonimia con que habitualmente se manejan los términos de «experimentación»e «investigación».

La investigacion va encaminada a la búsqueda de un conocimiento de la realidad física, que obliga a mantener la verdad durante todos los pasos por los que atraviesa la investigación, desde el planteo del problema objeto del estudio, la realización de los experimentos y el subsiguiente análisis de los resultados.

Estos pasos deben ser dados por el científico en libertad y con responsabilidad. Su reconocimiento ratifica la moralidad o la eticidad hoy negada de la ciencia, puesto que «la moralidad de los actos está definida por la relación de la libertad del hombre con el bien auténtico» (SV. n. 4).

La experimentación, en cambio, citando a Claude Bernard es «el conjunto de artificios por los cuales el hombre de ciencia busca realizar una observación rigurosa de los hechos, que ocurren en condiciones mantenidas constantes».

Otra de las diabólicas paradojas que vive el mundo científico en la actualidad es el de, por un lado, reunirse con periodicidad para redactar manifiestos, declaraciones y códigos referentes a la experimentación humana y, por otro, leer en publicaciones científicas de primer nivel, trabajos de experimentación, cuyo factor dominante es el beneficio en el plano económico, relacionados con el aborto provocado de embriones de cinco meses, programados artificialmente con el fin de que la sustancia nigrans de su cerebro o el tejido fetal adrenal se inyecte a pacientes portadores de la enfermedad de Parkinson .

Con estas premisas, citando los nn. 20 y 23 de la EV., dice que para promocionarle a la dignidad humana un fundamento firme, es preciso concebir al hombre como «imago Dei», pues el único modo de entenderlo capaz de justificar su carácter de fin en sí mismo.

Desde esta óptica, al juicio del relator, es necesario enumerar los principios dominantes, que hay que tenerlos en cuenta, en toda investigación y experimentación: 1) el interés de la ciencia médica, 2) el interés individual, 3) el interés de la comunidad, el «bonum comune».

La naturaleza humana es la misma desde siempre. Sus principios y leyes debieran ser iguales para todo; sin embargo, los cambios culturales y el progreso científico que marcan nuestra vida moral parecen diluirse en estos tiempos. Se olvida que «no es lícito ni siquiera por razones gravísimas, hacer el mal para que produzca el bien», que ni siquiera la buena intención basta para justificar la bondad de una acción. 
En razón de esta confusión, el relator considera conveniente repetir los conceptos vertidos por el Papa Pío XII, cuando decía que en materia de moral médica debieran considerarse tres ideas básicas:

1) La moral médica debe basarse sobre el ser y la naturaleza. Y esto, porque ella debe responder a la esencia de la naturaleza humana, a sus leyes y relaciones inmanentes. He aquí por qué una moral médica puramente positivista se niega a sí misma.

2) La moral médica debe ser conforme a la recta razón, a la finalidad y ordenarse según los valores. La moral médica no vive en las cosas, sino en los hombres, en las personas, en los médicos, en su juicio, su personalidad, su concepción y realización de valores.

3) La moral médica debe enraizarse en lo trascendente. El deber moral no depende de la complacencia del hombre. La acción moral es su cometido. Este fenómeno obliga a reconocer que la moral médica posee en último análisis un fundamento y una regla trascendente (SS. Pío XII, Discurso a la 171 Asamblea de la Asociación Médica Mundial (30 septiembre 1954). En López Medrano).

Tras este recordatorio, el relator entra en el campo de la Bioética, y citando el magisterio de la iglesia (CC. art. 2.275; CDF, instr. «Donum vitae», 1,3), dice que «Algunos intentos de intervenir en el patrimonio cromosómico y genético no son terapéuticos, sino que miran a la producción de seres humanos, seleccionados en cuanto al sexo u otras cualidades prefijadas», manipulaciones contrarias a la dignidad pesonal del ser humano, a su integridad y a su identidad (CDF, instr. «Donum vitae»,1,6).

Termina su comunicación, manifestando que la situación en el mundo científico dista mucho de regirse por estos principios básicos, de una Etica Común. Primero, porque la investigación se complica cuando se practica sobre el hombre y, aún más, cuando se acerca a algo tan personal y distintivo del género humano como son la mente y la sexualidad. Segundo, porque las presiones económicas hacen olvidar muchas veces los principios de orden moral antes mencionados. Tercero, porque la tecnología derivada de la ciencia es una herrramienta de poder, no sólo económica, sino también política. Entramos así en una nueva disciplina: la de la Geopolítica de la Ciencia.

12. El prof. de Derecho Privado y Derecho Romano en la Universidad de Salzburg, Theo Mayer-Maly, versa su conferencia acerca del II Diritto alla Vita e la trasmissione della Vita nei diversi sistemi de esperienze giuridiche contemporanee».

Se trata de una extensa intervención en la que podemos distinguir tres partes: una introducción, en la que hace referencia a algunos textos legales internacionales y nacionales, en los que se proclama el derecho y 
la protección de la vida. Una exposición de la normativa legal acerca de ocho Estados europeos sobre temas concernientes a la vida, como aborto, biotécnica de la reproducción, transplante de órganos, eutanasia. Y unas consideraciones finales.

1) Introducción.

Al comienzo de esta centuria en todos los países civilizados existía una protección total a la vida, regulada por leyes ordinarias. En ningún lugar se permitía o toleraba el aborto, sino que estaba severamente castigado. El principio de derecho común «nasciturus pro iam nato habetur» tenía sus consecuencias jurídicas. En ninguna parte se admitía la eutanasia. El suicidio, en sí mismo, no era punible, pero sí lo era la ayuda para quitarse la vida.

Solamente en los textos recientes que garantizan los derechos fundamentales se menciona el derecho a la vida, los debidos, principalmente, al exterminio en masa de judíos y de personas incapacitadas.

Entre los documentos internacionales más importantes que garantizan la protección de la vida, cita: la Declaración Universal de los Derechos humanos, de 10 de diciembre de 1948, en su art. 3., afirmando que todo individuo tiene derecho a la vida, a la libertad y a la seguridad de su persona. El Convenio Europeo para la protección de los Derechos humanos y de las libertades fundamentales, de 4 de noviembre de 1950, en su art. 2, «en el que se dice "el derecho de toda persona a la vida está protegido por la ley"», estableciendo cuatro excepciones: a) Pena de muerte como ejecución de la sentencia de un tribunal, en el caso de que el delito esté castigado con esta pena por ley; b) Muerte como consecuencia del recurso a la fuerza absolutamente necesario para asegurar la defensa de cualquier persona contra la violencia ilegal; c) Muerte como consecuencia del recurso a la fuerza absolutamente necesaria para efectuar una detención legal o para impedir la evasión de una persona detenida legalmente; d) Muerte como consecuencia del recurso a la fuerza absolutamente necesaria para reprimir, de conformidad con la ley, una revuelta o una insurrección. El Pacto internacional de Derechos civiles y políticos, de 19 de diciembre de 1966, en su art. 6, calificando el derecho a la vida como inherente a la persona humana y garantiza su protección por la ley. Por otra parte, dice: «Nadie podrá ser privado de la vida arbitrariamente». Los párrafos siguientes del art. 6 de este Pacto se ocupan del genocidio, hoy llamado «purga étnica» y de la pena de muerte. Sobre este punto el ponente remarca que la actitud de la EV. es de completa reserva.

Solamente unos pocos Estados han incluido en sus Constituciones la protección del derecho a la vida, garantizada internacionalmente. Entre esos Estados están España, art. 15, en el que se establece que todos tie- 
nen derecho a la vida y a la integridad física y moral (CE. del 29 de diciembre de 1978) y Alemania, en cuya Ley Fundamental (Grundgesetz), n. 2 del art. 2 se lee: «Todos tienen derecho a la vida y a la integridad física», añadiendo a continuación: «Estos derechos sólo podrán ser coartados en virtud de ley».

2) Panorámica legislativa de diversos Estados.

El ponente expone sucintamente la legislación de diversos Estados sobre problemas relacionados con la vida: aborto, biotécnica de la reproducción, transplante de órganos, eutanasia.

Entre los Estados citados por el ponente (Alemania, Suiza, Austria, Hungría, Holanda, Bélgica, Italia y España) vamos a limitarnos a Alemania.

a) Aborto

La regulación del aborto en Alemania ha pasado por diversas fases. Hasta 1974 el aborto era punible. Con posterioridad la ley n. ${ }^{\circ} 5$ para la reforma de la legislación penal introdujo una «regulación de plazos» (Fristenregelung), que dejaba sin castigar un aborto llevado a cabo en las trece primeras semanas de gestación. En aquella ocasión, el Tribunal Constitucional no aprobó esa disposición, derogándola en su decisión del 25 de febrero de 1975, al considerar que violaba el art. 2 del Convenio Europeo para la protección de los Derechos Humanos y el art. 2 de la Ley Fundamental.

Por la Ley n. 15 de Reforma de la legislación penal, en 1976, el legislador adoptó el sistema de las «indicaciones». Con la Ley de Reforma de la ayuda a las gestantes y a la familia, de 21 de agosto de 1995 (Schwangeren und Familienhilfeänderungsgesetz) se ha introducido el sistema de plazos.

Resumiendo, podemos decir que en la actualidad el aborto no es punible en los casos siguientes:

a) Cuando se lleva a cabo por libre deseo de la madre, la cual deberá acreditar que se ha sometido al asesoramiento de un médico o de un centro de asesoría autorizado, siempre que el aborto se practique en los tres primeros meses del embarazo.

b) Cuando esté en peligro la vida de la gestante o haya peligro de graves perjuicios físicos o psíquicos para la madre.

c) La literatura jurídica admite también el supuesto de que lo previsto en el apartado anterior se dé en el «nasciturus». Pero la constitucionalidad de este supuesto es problemática.

b) Biotécnica de la reproducción

Los abusos de la llamada medicina de la procreación están previstos en la Ley de protección de embriones, de 13 de diciembre de 1990 (Embryonenschutzgesetz). Esta ley considera como embrión «un óvulo 
humano capaz de desarrollarse, ya fecundado, desde el momento de la cariogamia. Esta ley penaliza la venta de embriones, la determinación del sexo con ocasión de la inseminación, el cambio artificial de la información genética de una célula germinal humana y la clonación.

A juicio del ponente, esta ley ofrece una laguna respecto a una inequívoca reprobación de la inseminación heteróloga, así como a una prohibición estricta de la maternidad subrogada. Los tribunales tienden a calificar los contratos de maternidad subrogada como contrarios a las buenas costumbres, «contra bonos mores».

c) Transplante de órganos

Desde 1973 en Alemania se han discutido los problemas legales del posible transplante de órganos. En septiembre de 1978 el Gobierno Federal aprobó un borrador de Ley de transplante de órganos, pero ni éste ni otros sucesivos han llegado a convertirse en ley.

Uno de los problemas principales es el concepto de muerte. Durante veinte años, el factor decisivo para la mayoría ha sido la pérdida irreversible de la actividad cerebral y no el colapso total del corazón y de circulación. Esta postura se ha debilitado considerablemente por el embarazo de una mujer, que había sufrido la pérdida irreversible de la actividad cerebral.

El tan frecuentemente invocado «desarrollo actual de la ciencia» no conduce, por sí solo, a una decisión convincente. Las observaciones de las ciencias naturales deben ir acompañadas de evaluaciones responsables para detectar los peligros del abuso de los avances científicos.

d) La eutanasia

Como no se ha llegado a un resultado legislativo, es necesario guiarse por la jurisprudencia más preeminente.

Un caso concreto: por sentencia del 4 de julio de 1984, un médico fue absuelto por el Tribunal Federal de la acusación de omisión de asistencia debida. El médico se había encontrado con una persona, que aún estaba viva, después de un intento de suicidio y no le proporcionó un cuidado intensivo, con el que hubiera podido salvar la vida del paciente. El médico estuvo con él hasta que murió.

El Tribunal Federal sostuvo que un médico no debe acceder a los deseos del suicidio de un paciente. El argumento principal de la absolución fue que su decisión no podía calificarse como injustificable desde el punto de vista legal, porque había estado con el paciente hasta su muerte en una situación límite por respeto a la personalidad del difunto.

En 1986, la 56 reunión de los juristas alemanes discutió la cuestión de si existe un derecho a la propia muerte. En el ámbito de una eutanasia pasiva, que se ha extendido considerablemente por los avances de la medicina intensiva, se acentúa más enérgicamente la voluntad del paciente. 
3) Consideraciones finales

El ponente, tratando de resumir las impresiones que uno saca de las disposiciones de los Estados, manifiesta «simplemente que esas impresiones son sofocantes y pésimas».

Hacia mediados de los años setenta de nuestra centuria, los países más cultos y ricos de Europa han abandonado la protección de la vida del no nacido con una uniformidad casi fantasmal. Solamente algunos Estados la han mantenido. El número de Estados, que se han conformado con el sistema de las «indicaciones» para autorizar el aborto, ha sido pequeño. Han proliferado los intentos de introducir una indiferenciada «disolución de plazos»(Fristenlösungen). La relativización de la protección de la vida del no nacido ha sido pararela a la relativización de la vida de los enfermos incurables y de los moribundos. En relación con estos temas, no se ha tomado en serio el art. 2 del Convenio Europeo para la protección de los Derechos Humanos. Y esto hay que decirlo, también, del Tribunal Europeo de Derechos Humanos.

La protección de la vida que, a nivel interno, está garantizada por las Constituciones de algunos Estados, ha resultado ineficaz, más en Alemania que en España. En muchos Estados los Tribunales constitucionales han tenido que intervenir en el tema del aborto, desempeñando un papel lamentable. No era éste el caso de Alemania en un comienzo, pero la tendencia a nombrar los miembros de los Tribunales con criterios políticos, ha tenido consecuencias fatales para la problemática, que estamos tratando.

Es sorprendente - dice el ponente- cómo muchos incumplimientos del deber de protección de la vida han sido precedidos por una proclamación del respeto a la vida. Es extramadamente difícil encontrar las razones de estos incumplimientos. ¿Estamos ante un cambio colectivo de conciencia? ¿O nos encontramos con los resultados de una sutil campaña?

El ponente termina su intervención con una reflexión relacionada con el Estado del bienestar: los expertos nos dicen que nuestras pensiones y nuestro seguro de enfermedad no podrán financiarse en un futuro próximo, si no cambia la pirámide de población. Esto nos exige que dejemos de matar a los futuros contribuyentes. El día en que todos nos demos cuenta de esto, puede ser demasiado tarde.

13. Se da lectura a dos comunicaciones. La primera por el prof. Carl Anderson, Decano del Instituto Juan Pablo II para el Matrimonio y la Familia: Il diritto alla Vita nel sistema giuridico americano, y la segunda por el prof. Heinhard Steiger, Il diritto alla Vita nel sistema constituzionale tedesco. 
El prof. Anderson comienza con una advertencia preliminar: el «sistema» legal americano está compuesto por cincuenta sistemas correspondientes a los cincuenta Estados de la Unión y por un sistema nacional federal.

Hasta que el Tribunal Supremo de los Estados Unidos no determine con claridad la norma constitucional aplicable a una cuestión legal concreta, los distintos Estados frecuentemente desarrollan principios diferentes y, en ocasiones, antagónicos.

Por ejemplo, esa era la situación respecto al aborto y al derecho a la vida antes de la célebre decisión del Tribunal Supremo de los EE.UU. en 1973, en el caso Roe contra Wade. Con aquella decisión el Tribunal marcó una pauta nacional respecto a la legalidad del aborto. Hasta esa fecha los cincuenta Estados de la Unión mantenían una amplia variedad de enfoques en el tema del aborto. Treinta Estados permitían el aborto solamente para salvar la vida de la madre. Dos Estados permitían el aborto para salvar la vida o proteger la salud de la madre. Un Estado permitía el aborto para salvar la vida de la madre o cuando el embarazo era el resultado de una violación. Trece Estados permitían el aborto en las circunstancias señaladas en relación a la vida y salud de la madre, cuando el embarazo era consecuencia de una violación o incesto, o cuando el «nasciturus» tenía alguna anomalía. Cuatro Estados permitían el aborto sin ninguno de los requisitos anteriores, pero señalaban unos límites temporales, dentro del embarazo, para poder realizarlo.

Después de esta advertencia previa, el relator presenta una serie de casos concretos resueltos por diversos Tribunales, incluido el Tribunal Supremo de los EE.UU., que abarcan el aborto, muerte y donación de órganos, eutanasia, presentándonos el fondo doctrinal que, a su juicio, subyace en la resolución de todos estos casos.

Los Tribunales Federales, más que ver el derecho a la vida como fundamento del ejercicio de la libertad, ponen en primer plano el interés del individuo por la libertad, si bien limitado por el interés del Estado por proteger la vida. Dicho de otra manera: los Tribunales Federales han adoptado una creciente visión expansiva de la libertad, entendida ésta como autodeterminación autónoma, al mismo tiempo que van estrechando el alcance del derecho a la vida.

Así, el relativo esfuerzo del interés del Estado por proteger el derecho a la vida disminuye en la medida en que se deterioran las condiciones médicas o físicas de la persona. La lógica del análisis sugiere que, si el interés del Estado por la vida disminuye en la medida en que se deterioran las condiciones médicas y físicas de la persona, pocas razones existen para pensar que, de la misma manera, no disminuirá el interés del individuo por la vida. 
El peligro de esta Jurisprudencia de libertad radica en que el derecho a la vida solamente puede ser reconocido, en tanto en cuanto el individuo es capaz de autodeterminación autónoma. De esta forma, la capacidad para la autodeterminación autónoma se convierte en la medida para el reconocimiento del interés del individuo por la vida.

El relator concluye su intervención con estas palabras: «En los EE.UU. hoy, el derecho a la vida protegido por la Constitución está desvaneciéndose en aquellos mismos planos de la vida, en los que tradicionalmente el Derecho ha puesto especial cuidado en su protección».

El prof. Steiger comienza la lectura de su comunicación, manifestando que, a tenor de lo que se ha dicho en el Aula, debe modificar su texto. Según él, se han hecho críticas, que merecen respuesta. La Ley Fundamental, art. 2, pág. 1, establece que la dignidad del hombre es inviolable. El titular es el ser humano desde el momento de la fecundación. La Ley Fundamental establece la defensa del titular, la protección de la vida y la ayuda a mantenerla por parte del Estado. Afirma que el «nasciturus» tiene derecho a la vida, que no puede eliminarse por deseos de la madre y que el aborto es punible. Reconoce, no obstante que existen dificultades, v.g., la salud de la madre, en cuyo caso se requiere un certificado oficial médico para admitir el aborto. En cuanto al embrión, se le considera que tiene vida humana. Actualmente se tiende a la legalización de la intraimplantación. La esterilización no se permite. Repecto a la eutanasia, no es constitucionalmente admisible, si bien existe un debate abierto al respecto, en el que queda claro que no basta la voluntad del enfermo. En referencia al transplante de órganos, se impone antes cerciorarse de cuándo puede hablarse de muerte cerebral, sin deslegitimar el acuerdo del donante. En resumen - dice el relator- la situación es positiva, aunque existan zonas conflictuales y riesgos de dejar la vida a merced de terceros.

14. El prof. Giuseppe D'Alla Torre, Rector de la Libera Università Maria Ss.ma Assunta-Lumsa de Roma, presenta su ponencia titulada: «Le leggi contro la Vita: il loro significato politico-giuridico».

Resaltando la extensión de su ponencia, entregada a los congresistas como texto provisional, intentaremos, a nuestro leal saber y entender, resumirla.

El ponente plantea la cuestión bioética, cuya tema central es la tutela de la vida, como relevante en la peculiar prospectiva de las relaciones entre la Iglesia y comunidad. Como prueba de este aserto, se remite a las reacciones suscitadas tras la publicación de la encíclica «Evangelium vitae».

Subraya las profundas ambigüedades en el mundo del derecho en relación con la tutela de la vida. Ambigüedades a nivel nacional como pla- 
netario, tanto en la legislación como en su interpretación y aplicación administrativa y judicial. Pone como ejemplo, al respecto, la orientación del todo opuesta relevable por la jurisprudencia constitucional alemana e italiana, es decir, relativa a dos Estados con Constituciones bastante semejantes, teniendo un fuerte engarce iusnaturalista. De hecho, en una importante sentencia del Tribunal Constitucional Alemán, del 28 de mayo de 1993, se dice que entre los valores jurídicos protegidos por la Constitución no existe uno que tenga prevalencia sobre el resto, por lo que en el caso que deban contrastarse, debe prevalecer el criterio de una balanceada comparación. Precisamente en este sentido se había pronunciado el Tribunal Constitucional italiano en su sentencia n. 287/1975, al afirmar en su conclusión que «el interés constitucionalmente protegido relativo a la concepción puede colisionar con otros bienes, que gozan también de la tutela constitucional y que, en consecuencia, la ley no puede al primero dar prevalencia total y exclusiva, negando al segundo una adecuada protección». El Tribunal concluía afirmando que «no existe equivalencia entre el derecho no sólo a la vida, sino también a la salud de quien ya es persona, como la madre y la salvaguardia del embrión, que debe aún llegar a ser persona».

Desde este estado ambiguo que caracteriza la actual experiencia jurídica, a juicio del ponente, tres aspectos merecen indicarse:

Area de la juridicidad.

Por un lado, desde la sensibilidad por la protección de la vida a la creación de la categoría jurídica civilista, sobre todo, por la vía jurisprudencial, del daño biológico, entendido como lesión de la integridad psico-física de la persona. Tal integridad es, según la susodicha configuración, un bien protegido en sí y por sí, en relación al derecho a la salud, que generalmente goza de protección constitucional, prescindiendo de la capacidad laboral o beneficial del perjudicado.

Es evidente la relevancia del reconocimiento jurídico del daño biológico, respecto a la tutela de la vida en una prospectiva personalista. Si bien - manifiesta el ponente - las consecuencias de esta adquisición no han sido siempre coherentes. Así, la jurisprudencia italiana reconoce el daño biológico del concebido y, al mismo tiempo, reconoce el daño biológico sufrido por la madre por la intervención abortiva efectuada «ex lege», pero clínicamente no conseguida, dando lugar al nacimiento.

Por otro lado, en el sentido de la des-legislación de sectores relevantes en el mundo de la bioética. Este fenómeno tiene muchas caras: puede ser el resultado de la no intervención del legislador (en materia de la reproducción artificial de la vida); o de la elección del legislador de despenalizar una determinada materia, sin que sea sustituida esta despenalización por un sistema sancionador civil y administrativo eficaz (es el caso 
de muchas legislaciones sobre el aborto); o, aun, la opción legislativa por un «derecho débil», meramente procedimental, que no hace elecciones valorativas y no toma posición entre los intereses en conflicto (es lo que sucede en diversas legislaciones sobre las prácticas de fecundación artificial). Piénsese, también, en los casos en los que la intervención del legislador es sustituida por otros sujetos, como un Colegio profesional, cuyos códigos deontológicos pueden leerse como signo del retroceso de la juridicidad, ofreciendo una tutela débil e indirecta y, de todas formas, ausente, en el caso, de la intervención de un tercero respecto a los intereses en conflicto.

Area de los sujetos protegidos.

Los debates bioéticos y biojurídicos han abierto la discusión sobre la subjetividad jurídica en referencia a la vida humana. El problema se ha puesto, partiendo de la biología y de la genética acerca del comienzo de la vida humana, así como, en el plano filosófico, respecto al concepto de persona humana. En el mundo del derecho el problema se ha desarrollado en torno al concepto de la subjetividad jurídica, con referencia específica al nacimiento de la titularidad del derecho a la vida.

El ponente manifiesta que dichos debates han tenido el mérito de cuestionar el aborto. De hecho, ante el uso de las técnicas de reproducción artificial, ante el problema de los «embriones supranumerarios», a la licitud o no de la experimentación no terapéutica sobre los embriones humanos o a la producción de los mismos para uso comercial, se nota una convergencia acerca de la necesidad de establecer legislativamente un «estatuto del embrión», que establezca los confines y límites.

Esta toma de conciencia conlleva a la cuestión del aborto. Prescindir del aborto, equivaldría a aceptar un tratamiento diverso, en cuanto a la tutela jurídica, entre individuos humanos originados artificialmente e individuos originados naturalmente, con la ventaja que los primeros serían los protegidos, y con la clara contradicción del principio de igualdad, sin distinción por razones personales y sociales.

Consideraciones análogas pueden hacerse respecto al fin de la vida, como revela ejemplarmente la experiencia holandesa. La ley del 30 de noviembre de 1993 basa la despenalización de la eutanasia en el hecho que la intervención activa del médico venga previa solicitud expresa del paciente; la praxis refleja que la distinción fundamental entre interrupción «voluntaria» e interrupción «involuntaria» va perdiendo significado. Esto indica, por un lado, que la esfera jurídica subjetiva tiende a alargarse, pues se transfieren al paciente atribuciones que corresponden al médico; por otro lado, dicha esfera viene reducida, llegando a un desdoblamiento entre individuo y persona, en la medida en que se transfiere al médico el derecho de la vida o de la muerte. 
Area de la relación médico-paciente.

Según el ponente la experiencia jurídica camina desde una medicina paternalista de tradición occidental hacia una medicina contractual. La legislación y, sobre todo, la jurisprudencia tienden cada vez más a la afirmación del principio de autonomía en la relación médico-paciente, delineando, en consecuencia, configuraciones jurídicas en torno al concepto de los derechos -inviolables- del enfermo, más que en torno al bien del propio enfermo. Y, a un tiempo, la misma experiencia jurídica manifiesta, cada vez más, orientaciones de signo opuesto: el incremento sin límites del poder del médico.

A veces el fenómeno puede reconducirse hacia un burdo y banal efecto de vuelta atrás a la medicina paternalista. Se piense sólo en la experiencia norteamericana más avanzada y significativa referente al tema del consentimiento notificado por el acta médica, donde la obligación - $\mathrm{O}$ por lo menos la praxis - de la manifestación de la voluntad dada por escrito, se ha convertido, poco a poco, de ser un instrumento tutelar del paciente a ser un instrumento tutelar (civil o penal) del médico.

El fenómeno en cuestión, por otra parte, es fruto de una más profunda ambigüedad, a causa de la cual la experiencia jurídica conduce sustancialmente hacia una meta del todo opuesta a la que sustancialmente se persigue. Caso típico es el holandés sobre la eutanasia, en el que la legislación termina por incrementar el poder del médico en detrimento de la así dicha «reapropiación» de sí por parte del paciente, que es típica de una medicina contractual. De forma que se ha podido afirmar con sutil ironía, que «después de todo, la eutanasia es el último paso en el intervencionismo médico: el sufrimiento se alivia con cualquier medio, incluso, si este medio conlleva la muerte del paciente.

En conclusión, se puede observar cómo las contradicciones que marcan, en la edad contemporánea, la experiencia jurídica en el tema de la tutela de la vida, sean fruto del vuelco de una relación: del primado del derecho sobre la política al primado de la política sobre el derecho, cuyo efecto ha sido reducir el derecho a una mera realidad formal, extremadamente mutable y no coherente en la complejidad de sus imperativos. En otras palabras, el derecho ha llegado a ser instrumento autoritario de la imposición de la voluntad del más fuerte. Este dato, paradójicamente, se hace más evidente en las democracias, en donde la voluble voluntad de las variables mayorías enriquece el ordenamiento de normas contradictorias, que encuentran su razón, no en la lógica del derecho, sino en la voluntad dominante que se forma, de vez en cuando, sobre una específica cuestión.

Las leyes contra la vida y el sentido de la política.

El ponente se detiene en el concepto del bien común como fin último de la vida social. El bien común exige que la persona sea tratada como 
fin, no como medio. En consecuencia, demanda la vida de cada individuo y está orientado preliminarmente a su tutela. Cada vez que la ley dispone o permite la violación de la vida de un inocente, se niega este bien.

A la luz de la concepción clásica, en la medida que el principio de la indisponibilidad de la vida es empequeñecido en el ordenamiento positivo, la política misma se ve privada de sentido.

El ponente, consciente de la pluralidad de concepciones políticas, considera posible abrir una vía común entre las mismas, cuyo punto de engarce es el hecho del reconocimiento de los derechos humanos. Se trata de derechos preexistentes al ordenamiento jurídico positivo, que, en consecuencia, reconoce, no atribuye; inmutables en el tiempo e históricamente determinantes en el terreno del «ius positivum».

El ponente, dejando el debate sobre el fundamento, en cuanto está fuera de lo que se le ha encomendado, manifiesta que los derechos humanos, en la sociedad post-moderna, representan el nuevo rostro de la laicidad del Estado. Si, de hecho, laicidad del Estado es una expresión para indicar la existencia de unos límites al poder, dimensiones de una realidad, sustraídas a la soberanía temporal, desacralización de la política, los derechos humanos están fuera del orden de la política y, a un tiempo, la delimitan. Por consiguiente, en el caso de unas leyes contra la vida, la política invade un campo que no es el suyo.

Desde el punto de vista de la historia del pensamiento político y jurídico — dice el ponente- es interesante advertir que el eclipse del concepto del bien común ha sido allanado y acelerado por la doctrina de los derechos humanos, en la medida en que el fin social, objeto de la política, ha sido individualizado en la garantía de los derechos del individuo, considerado exclusivamente en sí. Mas también es interesante recordar el reciente magisterio social de la Iglesia, superando las posiciones recíprocamente excluyentes, en la medida en que los derechos humanos son considerados como contenido principal del bien común y deber propio de la actividad política.

La leyes contra la vida y el sentido del derecho.

El ponente nos habla de la doble tentación, en la que puede caer el Estado. Una, servirse del derecho positivo para imponer una ética. La otra, traducir en normas la praxis social inspirada en ciertos principios éticos, con la consecuencia de que, a través del derecho positivo, se impone una ética a las otras. Sin decir después, en relación con esta segunda tentación, de la contradicción ínsita al querer remitir los juicios de valor ético al principio de la mayoría.

Se subraya, por una parte, que el pluralismo ético cae en un círculo vicioso, del que parece imposible salir sin contradicciones. De hecho, si el legislador hace propia una ética entre tantas, viola el principio de la 
laicidad; si en nombre de este principio se abstiene, deja el campo libre a los conflictos y al más fuerte. Por otra parte, el «politeísmo ético» hace imposible, en la práctica biomédica, tomar una decisión en base a unos principios éticos compartidos. De esta situación contradictoria nacen las objeciones de conciencia.

Ha habido tentativas de salir de este círculo vicioso. Una es la así llamada «derecho débil», que consiste en un contenido meramente reglamentario por parte del Legislador, que, si bien no se niega su fuerza sugestiva, es incapaz de resolver los conflictos que surgen en el cuerpo social, como se señala en la EV.

Paradigmático resulta el «derecho débil» en el caso de la fecundación heteróloga. Se puede regular la acumulación del semen, su selección, su control por evitar las enfermedades, su idónea conservación en los bancos del semen, la modalidad del seguimiento en las prácticas de fecundación. Pero jamás podrá resolver los conflictos que nacen del interés del donador del semen al anonimato y el del concebido por conocer su paternidad; el interés de la mujer célibe por tener un hijo a través de la fecundación artificial y el interés del hijo por tener un padre; el interés del marido de la mujer fecundada con semen de un donador a desconocer la paternidad y el interés del así procreado a ver reconocidas las responsabilidades genitoras del hombre.

De lo que precede se evidencia cómo el problema de la laicidad del Estado viene a ser substancialmente el problema de la laicidad del derecho. Y, además, se demuestra la imposibilidad de un derecho laico, entendiendo con esta expresión un derecho neutral frente a las diversas tablas de valores éticos profesadas en el cuerpo social.

A juicio del ponente, en el positivismo jurídico se encuentra, probablemente, la raíz del problema y de todos los equívocos que se derivan. Si la temática de los derechos humanos pone en evidencia la subordinación del derecho positivo a un modelo jurídico superior, a cuya luz valoramos la legitimidad, ¿no cabe interrogarse si el problema de las opciones éticas del derecho no deba considerarse a la luz de la susodicha relación?

El problema no está, por lo tanto, si el derecho debe elegir una entre las tantas tablas de valores éticos, sino en ver cuál sea la especificidad estructural del derecho, es decir, la individualización de lo que le es «proprium» en el plano del «deber ser».

El derecho es instrumento de comunicación universal entre los hombres, es el ser estructura de convivencia y paz. Por decirlo así, su «ética» está caracterizada por algunos principios basilares, cuales son el recíproco reconocimiento de la dignidad del ser humano, la simetría de las posiciones y, por tanto, la reciprocidad de los derechos y deberes, el criterio de justicia en las definiciones de las relaciones intersubjetivas. 
Todo esto tiene gran peso de consecuencias significativas en el campo bioético: aborto, eutanasia, etc.

La agonía del derecho agnóstico y el rol de la Iglesia.

Según el «derecho agnóstico», fruto de la ideología liberal-radical, fundada en el agnosticismo religioso y el relativismo moral, la racionalidad de las leyes se da sólo por las decisiones de las mayorías; de la capacidad del legislador de emanar una norma capaz de salvaguardar una pluralidad de éticas y, por lo tanto, de praxis jurídicamente legítimas.

Según el ponente, este derecho ha llevado a la crisis del mismo derecho, evidente a los ojos de todos. Se impone la recuperación de la concienciación de la verdad del hombre, de los valores morales objetivos, de los derechos inalienables de la persona como derechos inscritos en un orden jurídico igual siempre para todos.

En esta dinámica se debe restituir a la religión el rol público que a la misma le compete.

15. Las voces que se oyeron tras la conferencia no hicieron más que remarcar lo ya dicho en referencia a la tutela del embrión, resaltando que en este terreno subyace lo económico en detrimento del sanitario. Se hace alusión a la Ley italiana de 1994 que, en el caso de intereses en conflicto, prevalece la salud de la madre, de ahí el homicidio voluntario, y a la Ley holandesa, diciembre de 1994, que posibilita la muerte del inconsciente por el médico, sin que se comunique estas occisiones. Se afirma la imposibilidad de solucionar la situación reinante, si nos mantenemos en el ordenamiento jurídico positivo. Urge ir a los principios universales, como indica el Santo Padre, remarcando que la política debe ser en interés de todos e instando al poder ejecutivo a quien compete dar las soluciones.

16. Se presenta dos comunicaciones. Una, titulada «Le leggi contra la Vita: analisi etico-culturale» por el prof. de Etica en la «Katolichi Universytet Lubelski-Polonia, Tadeusz Styczén. La otra, por el prof. de Filosofía de Derecho en la Universidad de Granada, Andrés Ollero, titulada: «Convinzioni personali e attività legislativa».

El prof. Styczén comienza su relación, aludiendo al título de su comunicación: «Las leyes contra la vida son de hecho una "contraditio in adiecto", pues la razón del ser del derecho es la tutela del bien del hombre, que exige ante todo - como suya una "conditio sine qua non"- la tutela del bien fundamental, que es la vida».

Para el relator tales leyes falsifican el sentido esencial de la ley, el mismo Estado como sujeto legislativo viola el principio de la justicia, por lo tanto, se autosuicida como Estado de derecho. La primera víctima de la violencia infligida en nombre de la ley y del Estado no es 
quien la sufre, sino aquel que lo inflige. De este modo cualquier forma de participación en un acto de un Estado de quitar la vida de seres inocentes, significa para cada uno de los que participan un acto de muerte moral suicida.

En esta situación, un análisis ético-cultural de las «leyes contra la vida» se reduce a desenmascarar de hecho tales leyes como un acto de actuación del absurdo de la «cultura de la muerte», con el objetivo de oponerse al proceso de la muerte de la cultura.

Con esto se diseña la finalidad de un análisis «ético-cultural»y su método.

El estudioso de ética llegará a este fin cuando 1) demostrará la validez universal de la afirmación: toda acción que realiza un absurdo es para el hombre, como ser racional y libre, absolutamente inadmisible y moralmente fatal y 2) (cuando) demostrará la validez objetiva de la afirmación: tal absurdo se hace real todas las veces que el hombre, como ciudadano de su Estado, participa en «una conjura contra la vida», participando junto al Estado en sustraer la tutela jurídico-legal a los seres humanos inocentes.

El ponente recuerda cómo en la Conferencia de El Cairo se ha intentado desenmascarar esta conjura de la vida y que no debemos olvidar Auschwitz. El estudioso de ética ante estos hechos debe cuestionarse en pro de una terapia. Según el relator se dan tres especies terapéuticas:

1) A los que no han aceptado, porque no han entendido, la terapia de despertar mediante la instrucción: el recurso a la información del lenguaje ético.

2) A los que han comprendido, pero no han aceptado, la terapia de la movilización: el recurso a la función parenética del lenguaje ético.

3) A los que no han querido comprender, la terapia, la más simple y la más difícil: volver a andar a las fuentes de la antropología y de la ética, y a la luz de ésas volver a ver la propia visión de la libertad.

En el primer caso sugerirá la pregunta si han tomado en consideración todos los posibles destinatarios de la fórmula «aborto seguro»; en el segundo caso, se añade a la información el momento de la parénesis: «Salva la víctima para salvarte a ti mismo»; en el tercero, el de confrontar la libertad en la prospectiva de su acto con la libertad con la que se revela como poder de negar lo que él mismo ha constatado.

Termina su relación, diciendo que el estudioso de ética, que sigue las huellas de Sócrates, advierte haber agotado la posibilidad de la palabra. Falta, sin embargo, el acto: el testimonio, un argumento ético por excelencia. Por eso K. Wojtyva dice en boca de Estalisnao, obispo de Gracovia: «La Parola non ha convertido, sarà il Sangue a convertire». 
El prof. Ollero, que en la actualidad es Miembro del Congreso de los Diputados en España, entra en la temática, señalando que la actividad política invita a privatizar las propias convicciones, bien para dejar campo libre a los no convencidos de nada, bien para estimular el ocultamiento de las auténticas razones de las propias respuestas políticas.

Es evidente - dice- que la democracia moderna, enraizada históricamente en planteamientos iusnaturalistas, se aposenta en el relativismo ético, con su afán de vincular a mecanismos formales la garantía de las expectativas de los ciudadanos, evitando depender de la mayor o menor exigencia ética personal de los gobernantes de turno.

Sorprendentemente, sin embargo, se insiste hoy en imponer al ciudadano, y muy especial al hombre público, un artificioso imperativo categórico, que le vedaría acudir a sus propias convicciones a la hora de abordar problemas de inevitable repercusión social.

Las razones en que pretende apoyarse tal propuesta son variadas. Se traza, por ejemplo, un abismo entre ética pública y ética privada, que obligaría a buscar en fuentes distintas de la propia conciencia los criterios decisivos. Se propone, incluso, una obligada neutralidad, que llevaría a abstenerse de tomar partido ante cualquier problema de especial relevancia ética.

Surge de inmediato la duda de si los formuladores llegan a ser conscientes del alcance de su propuesta de «privatizar» la solución de los problemas que — por razones éticas — se muestran más sometidos a la polémica.

A poco que se reflexione brota una doble perplejidad. Una, desde una perspectiva antropológica, una actitud individualista capaz de establecer a priori que el hecho de que una cuestión suscite, por razones éticas, una mayor polémica en el ámbito público, no implica que nos encontremos ante problemas sociales de particular gravedad. Otra, desde una perspectiva jurídica, pues cuando se insta a reducir al mínimo los supuestos respaldados por una sanción penal, es para reservarla a conductas que por su mayor calado ético producen particular agravio social.

De todo ello se deduce la insensatez de inhibirse por parte del responsable público o de proponer que tales acciones queden al privado arbitrio de cada ciudadano a la hora de tipificar conductas como punibles o a la hora de esclarecer las fronteras, cuya transgresión darían paso a una vulneración inconstitucional.

Para hacer justicia, se procura garantizar la imparcialidad. Igualmente para garantizar el respeto de los derechos humanos se tiende a huir de fórmulas de democracia directa, para depositar en los parlamentarios la obligada toma de conciencia de la situación. ¿De dónde puede obtener el parlamentario los criterios decisivos para su actuación? 
El relator afirma la complejidad que conlleva la representatividad. Considera que un parlamentario no puede neutralizar sus propias convicciones, facilitando al ciudadano - en la medida en que el sistema electoral lo haga posible- la adhesión o la repulsa de la conducta que de él coherentemente podría esperar. Esta exigencia de una actitud no inhibida parece traslucirse en el rechazo popular al sistema electoral de listas «cerradas» y «bloqueadas». El ciudadano se siente más satisfecho ante una representante personalizado, cuyas convicciones y coherencia de conducta está en condiciones de controlar, que ante una lista en la que se le exige deposite su confianza sin mayores matices. En este sistema electoral personalizado el parlamentario - aun al margen de todo mandato imperativo- está obligado a transparentar tanto sus propias convicciones como el grado de compromiso con ellas que asume en su actuación pública.

En el contexto actual de listas «cerradas» y «bloqueadas» pieza decisiva del «político indirecto» son los partidos políticos, cuyos programas electorales priman sobre las convicciones personales del parlamentario.

La progresiva pérdida de carga ideológica de los programas electorales tiende a convertir en decisiva la actitud de un sector del electorado, tópicamente calificado como «de centro». En tal ambiente encuentran fácil acogida recetas simplistas del tipo «no cabe imponer las propias convicciones a los demás» o «releguemos a lo privado cuestiones que tienden a romper el consenso social», dato que se revela en la política española respecto a los problemas relacionados con el derecho a la vida, que han ido perdiendo paulatinamente presencia en las ofertas programáticas de los partidos.

Es obvio - continúa- que el grado de vinculación ética de los programas electorales puede ser objeto de muy diversa valoración. Mas prescindiendo de tan importante matiz, la disciplina de voto acaba primando sobre los compromisos programáticos, por lo que el juego de las convicciones personales se verá remitido al grado de democracia interna, que en el caso español parece configurarse de manera particularmente vertical; descienden hacia las bases los dictados de la cúspide, que ausculta -más ahora entre los electores potenciales que entre los militantes- los oportunos cambios.

En esta tesitura se convierten en decisivos los medios de comunicación y los grupos públicamente activos.

Todo esto invita a profundizar en el auténtico dilema latente a la hora de abordar la presencia pública de las convicciones personales.

La democracia se apoya en el respeto a unos derechos humanos caracterizados como fundamentales, por lo que, en cuanto fundamentales, el respeto a tales derechos prima sobre el principio de la mayorías. Si así no fuera, estaríamos contabilizando una empírica «voluntad de todos», 
con decidida renuncia a elevarnos a una «voluntad general» de dimensión racional.

El malentendido de la doble racionalidad (razón y voluntad) lleva a presentar toda propuesta pública de exigencias objetivas como el intento de imponer, por imperativos sobrenaturales, una ética «contra-natura»; cuando la paradójica realidad es que quienes tal sugieren están negando en teoría la existencia de «naturaleza» alguna susceptible de transgresión.

¿Existe realmente una doble fuente de exigencias éticas en el ámbito público, derivadas del sistema democrático en un caso y del magisterio eclesiástico en el otro?

Para quienes responden afirmativamente al interrogante, tiene sentido hablar de intromisiones por parte del magisterio eclesiástico. Este pensamiento se sustenta en que «en ningún ámbito de la vida de la ley civil puede sustituir a la conciencia ni dictar normas que excedan la propia competencia».

La primera parte - manifiesta el relator - es difícilmente discutible. Problema distinto es qué ocurrirá cuando el rechazo moral de una ley se haga masivo, supuesto que los mismos teóricos del positivismo jurídico la admiten. En este caso, bien se admite la objeción de conciencia o, cerrada esta vía, el recurso a la desobediencia civil que — como hoy ilustran los «insumisos»- implica la asunción de las sanciones correspondientes a la infracción de la ley.

Para el relator el presunto dualismo planteado se diluye en la medida en que se produce una coincidente remisión a una realidad susceptible de servir de denominador común. El magisterio eclesiástico sobre cuestiones sociales no intenta tanto servir de vehículo a una normativa divinopositiva como garantizar el esclarecimiento de una realidad jurídico-natural. A su vez, los textos constitucionales que aspiran a la garantía práctica de los derechos fundamentales remiten también - a través de fórmulas como las de «contenido esencial», bienes jurídicos protegidos, etc. - a una realidad metapositiva.

Por ello, rebrota la evidencia de la imposible «neutralidad» de cualquier transferencia de debate a la esfera de la autonomía individual.

Conductas que - por los bienes jurídicos en juego y el reproche social que merecen- justifican la entrada en juego de la sanción penal, y no pueden quedar a la libre iniciativa de los ciudadanos, de modo que éstos puedan decidir, ateniéndose sólo a su propia conciencia. Los titulares de los poderes públicos no podrán eludir las responsabilidades que éstos llevan consigo.

Tampoco cabe apelar a la tolerancia para reconocer a algunos ciudadanos derecho a discrepar. Por definición, tolerar es dejar pasar una 
conducta que merece desaprobación. Pero sobre lo digno de desaprobación resulta difícilmente concebible fundamentar un derecho estable. Hablar de derechos supone abandonar el ámbito de lo tolerable para adentrarse en lo decididamente digno de protección.

Termina su comunicación, diciéndonos que si la democracia, en su sentido más pleno, es siempre una tarea para hacer, vinculada a garantizar los derechos fundamentales de los ciudadanos, es necesario asumir los ámbitos de responsabilidad que su papel político les reserve, aportando en su apoyo el máximo consenso social. Ello exige aportar las propias convicciones y llegar a un diálogo que enriquezca las instituciones democráticas, liberándolas de degenerar en el mero decorado de decisiones, faltas de transparencia y de razonada justificación.

17. El prof. de Filosofía del Derecho en la Universidades de Roma Toro Vergata y Pontificia Universidad Lateranense, Francesco D'Agostino presenta su ponencia titulada «La Teologia del Diritto Positivo: Annuncio Cristiano e Verità del Diritto».

El ponente da inicio a su disertación, manifestando la tentación de reducir el discurso teológico al derecho natural. El derecho natural se mueve todo él dentro de un horizonte ontológico y no teológico, como se hace patente en el hecho de que el debilitamiento de la ontología ha correspondido, en el pensamiento contemporáneo, un correlativo debilitamiento del iusnaturalismo. A veces, los iusnaturalistas han pensado que un buen puntal teológico puede ser útil para reforzar el fundamento de su doctrina. Pero no corresponde a la teología socorrer a las buenas razones del derecho natural: el bien se basta a sí mismo para defenderse y reafirmarse. El puntal teológico, en lugar de reforzarlo, lo debilita, obscureciendo su específico fundamento antropológico. El objetivo de la teología es el de ofrecer al derecho positivo un horizonte de sentido. ¿Bajo qué condiciones?

Una vertiente, en la que se sustancia el anuncio de la EV., es la llamada «a la continuidad con la tradición de la Iglesia» por corroborar la fuerte y cualificante afirmación de una necesaria conformidad de la ley civil con la ley moral. La denuncia de que carecen de valor jurídico todas las leyes que permiten o favorecen el aborto o la eutanasia, parece, en este contexto, no sólo como una deducción lógica operada a partir de una premisa, sino como memoria de una actitud y de un conocimiento que se revelan constantes en el Occidente. Análogamente, la fuerte recomendación a los responsables de la vida pública para que tomen decisiones valientes en favor de la vida (n. 90).

Desde esta luz, la valoración de la llamada a la fidelidad a aquel modelo de compromiso político, fundado en la diaconía, es una consecuencia específica del anuncio cristiano. 
Otra vertiente es la bíblica. La imagen bíblica del hombre que viene presentada por la EV., posee un intrínseco y exigente significado, que puede articularse en tres puntos esenciales, que corresponden a tres momentos esenciales del Kerigma evangélico. El primero es que el hombre es creado a imagen y semejanza de Dios, de lo que se desprende la sacralidad de la vida. El segundo es que el hombre es creado, en Adán, miembro de una única familia humana, por lo que la igualdad fraterna entre los hombres goza de un primado frente a toda posible diferencia e impone como principal virtud social la de la compasión y la de la solidaridad. El tercero, en cuanto así querido y así creado por Dios, el hombre tiene el don de la razón que — si bien en los límites de la creaturalidad- está capacitado de conocer la realidad, según verdad.

La sustancia de este anuncio es ciertamente un anuncio teológico; mas, a un tiempo, no es dogmático: no pretende un asentimiento prejudicial o irracional. Es un anuncio que llama - por usar el lenguaje de la EV.- a «una ley natural inscrita en el corazón del hombre» (n. 70).

El primer desafío de la EV. es en referencia al relativismo ético (n. 70). Este desafío nos lleva a la encíclica «Veritatis Splendor», que anuncia la capacidad del hombre de hablar según verdad y en la verdad.

Este anuncio es auténticamente teológico: nos invita a tener fe en la palabra de Dios, que nos asegura que el orden del mundo no es arbitrario, ni gobernado por fuerzas ciegas y obscuras; que el hombre en su operar en el mundo, es capaz de querer y de sustraerse a la omnipresente tentación de ceder a la ciega (y, por tanto, violenta) neutralidad del caso.

El segundo desafío concierne la democracia. El anuncio de la EV. es, al respecto, particularmente acentuado: o la democracia se funda sobre la explícita asunción de la dignidad humana y del bien común o es una palabra vacía (n. 70). Una democracia que relativiza todos los valores, que se limita a formular expresamente las «reglas de juego», deberá decidir quién deba ser admitido en el juego. Esta decisión no parece que sea difícil, porque existe una opinión compartida que no existe democracia si no existe la plena participación de todos los hombres en la vida de la sociedad civil: pero he aquí que emerge un valor sustancial, sobre el que fundar cualquier juego social: es necesario presuponer que a todos los hombres compete el derecho fundamental a formar parte de manera activa y personal en la comunidad política y que ninguna deliberación, incluso tomada por mayoría, respetando rigurosamente la vía procedimental, puede quitar este derecho. La EV., en definitiva, clama una democracia sustancial y no meramente formal, o, dicho de otro modo, una exhortación por la defensa y la promoción de los derechos humanos como fundamento y, a un tiempo, la razón misma de la existencia de la comunidad política. 
El tercer desafío emerge de las páginas de la EV. que conciernen el tema de la inocencia. En conformidad con el n. 72, el ponente manifiesta que la insistencia sobre la inocencia es de gran interés kerigmático: la inocencia hace perceptible cómo el anuncio de la Encíclica no tenga, en primer lugar, la vida como mero hecho biológico: el hecho biológico, que es la vida, encierra en realidad un valor absoluto, que el Estado debe respetar, porque, a partir de este respeto, a su vez, el Estado adquiere la razón de ser.

Todo sistema jurídico puede afectarse y construirse a partir de dos paradigmas. El primero es aquel por el que el derecho es estructura al servicio de la voluntad del poder: es la prospectiva que ama cualificarse como realista o como positivista, cuyo objetivo único es el de construir un sistema jurídico como un anónimo sistema de fuerzas contrapuestas, gobernado no en relación a la justicia, sino en relación a la efectividad del poder, cuya medida como poder jurídico, la encuentra únicamente en la dimensión sancionadora. En este horizonte el tema de la inocencia no tiene espacio; la inocencia no es un valor que el derecho esté llamado a tutelarlo, sino que se reduce a una calificación subjetiva, intrínsecamente vacía e insignificante, reconducible a una benigna concesión del sistema jurídico, una concesión que hace referencia a la misma soberana e impersonal arbitrariedad, con la que el sistema puede imputar una culpa a un determinado sujeto: entre culpa e inocencia no se da, en definitiva ningún paso axiológico; son dos dimensiones diversas por sus efectos sociales.

El segundo paradigma lee el derecho como estructura que tiene la razón de su existencia en la defensa de la inocencia. Como garantía de la coexistencia, como administración de la justicia, el sistema jurídico posee en la inocencia el propio presupuesto, la propia estrella polar: los hombres se relacionan recíprocamente, porque se fían los unos a los otros y confían en la recíproca inocencia. La inocencia hace referencia a la verdad de las relaciones interpersonales. Y por esto no existe nada más injusto que la violencia contra el más débil y nada más desagradable del engaño que mira a hacer aparecer culpable el inocente.

El ponente, haciendo alusión a las reacciones habidas respecto a la EV., muchas de ellas por una errada comprensión epistemológica de su mensaje y otras, aun comprendiéndola, teniendo la intención de rechazarla, dice que el rechazo equivale a negar que el horizonte que anuncia tenga fundamento. A mantener que el hombre no posea dignidad alguna intrínseca, que no sólo la fraternidad, sino la misma igualdad sea un mito $\mathrm{y}$, coherentemente, que la misma democracia sea un mito. Y que el derecho no está llamado a defender siempre y en cualquier parte a los inocentes, sino sólo aquellos que el sistema jurídico retenga — a su absoluta y arbitraria discreción- que deben ser defendidos. 
Termina su ponencia dirigiéndose a los juristas en concreto. Los juristas no pueden construir autopoéticamente su saber, porque la verdad del derecho está fuera del mismo derecho. En cuanto ciencia, también la jurisprudencia está llamada a respetar las exigencias de la reflexión coherente y sistemática de la dianoesi; en cuanto letrados también los juristas conocen bien la fatiga de la perinoesi, la dura fatiga que implica el deber de girar en torno al objeto. Pero no puede ser menos en los juristas el conocimiento que, junto a la dianoesi y a la perinoesi se pone la dimensión ananoética, aquella del anuncio kerigmático (defiende la vida). El kerigma lo que pretende es fundar una realidad nueva: ser todos hijos de Dios y consiguientemente, todos hermanos (n. 77).

18. Abierto el debate, se resalta que los poderes públicos no tienen voluntad de asumir el anuncio kerigmático. Según el ponente, el pensamiento teológico es la base iluminante del derecho, en cuanto muestra que el derecho en sí mismo no encuentra su justificación. El derecho necesita un alma. Por otra parte, el ponente, contestando a una congresista, que se autoconfiesa hebrea, que manifiesta la contradicción que encierra el Estado de Israel al proclamarse como Estado democrático y judío, dice que el precepto de amar debe fundarse en un concepto epistemológico: no sólo se debe amar porque se es hebrea, sino porque se es persona. Otro de los congresistas pregunta si el olvido de la teología hace referencia a la teología del pasado o a la teología de hoy, y acto seguido dice que no a la teología, sino a la transformación cultural se debe esta situación. La respuesta del ponente es que no hay lugar a este discurso. Al congresista que plantea si estima el ponente una lectura teológica-óntica de la EV., le contesta que se está refiriendo a una teología moral.

19. Seguidamente se lee dos comunicaciones. Una, con el título «Diritto naturale-Diritto positivo» por el prof. de Filosofía del Derecho en la Universidad de Oxford, John Finnis y la siguiente «L'Insegnamento della Filosofia del Diritto (Diritto naturale) nella Facoltà Di Giurisprudenza» por el prof. de Filosofía del Derecho en la Universidad de Lecceltalia, Antonio Tarantino.

El prof. Finnis comienza la intervención, recordando algunas verdades elementales sobre la ley natural.

Cuando deliberamos tan inteligentemente, como podemos para hacer una elección que sea la más racional posible, nos damos cuenta de ciertas razones fundamentales para la acción. Estas razones primarias y básicas de las que se derivan las demás razones para la acción, nos orientan hacia unos bienes igualmente primarios y básicos que queremos alcanzar con nuestra acción, bienes humanos fundamentales. Sto. Tomás llama 
primeros principios de la ley natural a los enunciados, que nos hacen considerar los bienes básicos como cosas buenas, que hay que lograr y su negación como cosas malas, que hay que evitar.

La expresión «ley natural» está compuesta por dos palabras: «ley»y «natural».

En esa expresión la palabra «ley» está tomada en un sentido análogo al que se utiliza al hablar de leyes de los Estados, o de los clubes o de los juegos. Pero, en esa analogía, las diferencias son, por lo menos, tan importantes como las semejanzas. La orientatividad de los principios de la ley natural, su normatividad, sus exigencias en nuestro razonamiento práctico y en nuestras elecciones no son sino orientatividad, normatividad y exigencias racionales de la verdad, que debe ser afirmada, porque la captamos por un acto claro del entendimiento y por una inconfundible intuición («insight»).

Los mencionados principios de la ley natural no solamente son inteligibles y verdaderos. Son, además, «naturales» o «de la naturaleza». Y puede llamarse naturales por dos razones:

a) Los principios de la ley natural son principios racionales y, precisamente, actuar racionalmente es el rasgo más específico de la naturaleza humana.

b) Los bienes hacia los que nos orientan los primeros principios de la ley natural son aquellos que más profundamente intervienen en el desarrollo integral de la naturaleza humana.

Dentro de la ley natural los autores distinguen los preceptos morales de la ley natural y los preceptos específicos de la justicia. Entre estos últimos, unos tienden a proteger bienes intrínsecos a la persona humana, como la vida y otros bienes que no lo son, v.g. la propiedad. En la reflexión ha sido posible identificar algunos derechos humanos o naturales como fundamentales: «derechos fundamentales del hombre».

Tarea primordial del Gobierno y de las leyes de un Estado es hacer lo posible para salvaguardar eficazmente los derechos de cada ciudadano y su pacífica armonización; la adecuada promoción de la honesta paz pública, que consiste en la ordenada convivencia en la verdadera justicia; la debida custodia de la moralidad pública.

Toda la legislación de un Estado es ley positiva. Su articulación con la ley natural puede darse de varias maneras: a) la ley positiva unas veces positiviza preceptos de la ley natural, que no admiten excepción, v.g. no se puede quitar nunca la vida a un inocente. b) Otras veces, la ley positiva impone preceptos, que se derivan de la ley natural por deducción. c) Otras veces, la ley natural no concreta nada sobre alguna cuestión concreta y la ley positiva determina y especifica el contenido genérico de la ley natural. En este último supuesto la ley positiva tiene un amplio mar- 
gen para elegir una opción u otra, pero, en todo caso, los principios de la ley natural constituyen una barrera que no se puede franquear.

Es sabido que muchos filósofos del Derecho, como Norberto Bobbio, defienden la posibilidad de una ley positiva válida, aunque sea injusta. Según esta teoría, una ley promulgada, después de haberse cumplido todos los requisitos formales para su producción, es una ley válida. Eso no impide que sea considerada injusta por algunos ciudadanos. En ese caso, éstos deberán trabajar para lograr que se cambie el contenido de esa ley mediante otra ley que cumpla, también, con los requisitos exigidos en la Constitución para su elaboración.

La doctrina tradicional afirma, como dice Sto. Tomás, que una ley injusta no es ley, sino abuso de ley, y, «aunque esté dotada del hecho social de la validez legal, no es verdaderamente una ley». Por lo tanto, en conciencia no hay obligación de obedecerla. Es la misma doctrina que se expone en la EV. (n. 73).

El relator, después de unas consideraciones sobre el problema que plantean este tipo de leyes a algunos profesionales, como los médicos, enfermeras, jueces, formula su opinión sobre la función de la ley positiva: «La ley positiva es, esencialmente, una empresa humana de la razón práctica que se esfuerza por promocionar bienes humanos y verdades prácticas».

Según los autores, la corrupción se introduce en las leyes de dos maneras:

1) La injusticia de una parte de la legislación se va extendiendo a otras partes de la misma, aduciéndose para ello razones de analogía que justifican las nuevas injusticias. Por ejemplo, el aborto por causas de salud física se amplía a causas de salud psíquica que, a su vez, incluyen como motivos poderosos deseos o aversión. Los principios que se aducen para justificar el aborto se extienden para abarcar el aborto eugenésico y el infanticidio. Cabe decir lo mismo con respecto a la eutanasia. La eutanasia voluntaria madurará rápidamente hacia una muerte no voluntaria de muchas personas, de las cuales se dirá —y tal vez se creerá- que, si pudieran hacer uso de su razón, desearían que se les quitase la vida.

2) La promulgación de la ley es siempre, quiérase o no, un acto de enseñanza, que pretende dar cuenta de aquello a que la ley natural y la naturaleza humana nos invita, si no es que nos exige. Una ley positiva injusta, sobre todo, si es intrínsecamente injusta, es un falso maestro. La intrínseca injusticia de sus invitaciones inmediatas a cooperar en una conducta injusta (wrongful conduct) está compuesta por las falsedades que proponen o insinúan: una academia de ulteriores y más amplias violaciones del bien del hombre para todos aquellos que no se desligan de los tentáculos del error y, conscientemente, encuentran su camino de espaldas a los verdaderos principios. 
El prof. Tarantino dice que la importancia de la Filosofía del derecho deriva del hecho, que existente la estricta conexión de la Filosofía del derecho con la ética, existente el pluralismo ético, se puede presentar una pluralidad de Filosofías del derecho (filosofía aristótelico-tomista, filosofía analítica, filosofía del neopositivismo lógico-jurídico), las cuales, obviamente, se proponen como portadores de los diversos tipos de valoración crítica en las confrontaciones del derecho positivo.

El problema estriba en el punto de partida; presupuesto que, a su vez, corresponde a un tipo de antropología filosófica. Una cosa, de hecho, es poner como fundamento el conocimiento del hombre en la totalidad de sus caracteres esenciales, otra en algunos de sus caracteres esenciales y otra en lo que no pertenece a su estructura ontológica, es decir, a sus caracteres no esenciales.

El verdadero problema, sin embargo, se presenta, en el momento en el que, aceptando como fundamento el conocimiento del hombre en la totalidad de sus caracteres esenciales, se intenta establecer a cuál de estos caracteres esenciales reconocemos una situación de privilegio.

Sostener como punto de partida el principio «veritas facit legem», indicar la «veritas» en la estructura ontológica de la persona, como punto ineludible de la teoría de las fuentes del derecho, significa indicar, con claridad, el fundamento de la justicia no en los principios de una justicia racionalmente convenidos, sino en los puntos firmes de la naturaleza. En una palabra, para que a la Filosofía del derecho le sea reconocida la función de valoración crítica, es necesario que la misma tenga algo que criticar, el derecho positivo; es necesario que sea reconocida la dicotomía derecho natural-derecho positivo, que está presente ya desde Sófocres.

Deseando sintetizar, en grandes rasgos, la situación de las doctrinas filosófico-jurídicas de nuestros días, el relator las concreta en dos líneas:

La línea «empírica» que asigna al derecho una función de control social, y es el baluarte del pensamiento historicista, positivista y neopositivista, que han vaciado la función de valoración crítica del derecho natural respecto al derecho positivo. Se trata de un vacío determinado por la sustitución de la trascendencia con la inmanencia, en el caso del historicismo; por la consideración de la inutilidad de reconocer a la filosofía la función valorativa del hecho empírico, en el caso del positivismo; por la reducción de la Filosofía del Derecho a rigurosos procedimientos lógicos, teniendo como punto de partida los resultados de las continuas encuestas sociológicas, en el caso del neopositivismo lógico-jurídico.

La línea «metafísica». El ponente distingue dos posturas dentro de esta línea: a) Quienes justifican la validez de sus valores en la estructura de la existencia (fundamento ontológico). En esta óptica, partiendo de datos ciertos que la sociedad ofrece en un determinado momento históri- 
co, el derecho es visto como creación y construcción del intérprete. Es una línea ésta que, en todas sus articulaciones, sólo «lato sensu» cabe remitirla a la tradición filosófica - jurídica clásica-, en cuanto no siempre consigue dar una valoración crítica del derecho positivo basada en los principios absolutos de justicia; b) La tradición filosófica-jurídica clásica, en cuyo ámbito el derecho natural y el derecho positivo no son completamente autónomos. El ponente esta situación la representa así: a) el derecho natural para valorar críticamente el derecho positivo debe conocerlo, y lo conoce porque su relación es vista desde la perspectiva que va del orden ontológico al orden ideal, como representación del orden ontológico, al orden ético, al orden político y jurídico; b) científicamente es correcto pasar del plano ontológico de una realidad, en nuestro caso de la persona humana, al plano de la definición gnoseológica de la misma, por lo que científicamente está justificado pasar de la descripción a la prescripción. En este ámbito se ve «el eterno retorno del derecho de la naturaleza». Por ello, decir Filosofía del derecho significa decir Filosofía de la ley ínsita en lo creado, en la naturaleza, cuya ley, tutelando el orden vital humano, tutela «los constitutivos» de la persona.

Es preciso precisar - continua el relator- a qué tipo de derecho natural nos referimos.

$\mathrm{Si}$, en los años 40, Rommen escribía que «ningún positivista afirmará ahora que este "ser una persona" y los derechos que dimanan, en primer lugar, el derecho de ser reconocido también jurídicamente como persona, "nacen de la voluntad del Estado"», hoy, lo que aún es peor, la facultad de reconocer los derechos fundamentales se fundamenta sobre la base de la naturaleza biológico-evolutiva del hombre. Así, se cualifica como persona sólo a los individuos humanos «autoconscientes, racionales y en posesión de un sentido moral mínimo», es decir, sólo los individuos autónomos. En consecuencia, no son personas, los embriones, niños, retardados mentales, etc.

Se lamenta de no ver la diferencia entre titularidad de los «constitutivos» (derechos) del individuo humano y su ejercicio, condicionado a su evolución ontogenética. Quienes no distinguen, critican a Kant por no haber diferenciado «la libertad como valor y la libertad como vínculo colateral» y encerrarse sobre la libertad como valor.

Lo que daña a estos pensadores - dice- es haber privilegiado excesivamente la dimensión relacional, el no haberse interesado por los «constitutivos» de la persona en su momento fundante. Tales pensadores debieran haber considerado en pro de su tesis, que la esencia del hombre no se agota ni en el sólo «vínculo colateral», ni en la sola individualidad de la persona. Debieran haber tenido presente que la «sociabilidad» es un elemento igualmente constitutivo de la naturaleza del hombre como lo es su racionalidad. 
La ética que proponen estos pensadores es una ética en la que se deja ver una libertad privada de leyes ontológicas, una racionalidad abstracta, individual, que puede decidir, precisamente abstractamente e individualmente, el tipo de programas de vida que cada ser humano puede formular.

Debieran prestar mayor atención a la sociabilidad de la persona y, conjuntamente a su fundamento: si así lo hicieran, se darían cuenta que: 1) de la estructura ontológica del hombre, de la sociabilidad del hombre, como su momento constitutivo, desciende la necesidad ontológica de la familia; 2) la familia es anterior al Estado; 3) la natural integración de los derechos y deberes se fundamenta en la esencia del hombre, en su sociabilidad y en su racionalidad.

En el contexto del derecho natural clásico la racionalidad y la sociabilidad implican un tipo de derecho positivo respetuoso de las leyes ontológicas, por el que es difícil la existencia de fugas peligrosas para la vida individual y social. No puede afirmarse lo mismo si el proceso social del perfeccionamiento del hombre es visto desde el derecho natural moderno. Si se parte del individuo sin vínculos recíprocos, con sus derechos al margen de su relación con los derechos de los otros o el punto de partida es sólo la libertad como «vínculo colateral», se justifica un derecho positivo, que prevé y tutela los derechos fundamentales, en la medida en que son aceptados y propuestos por la vía acordada o convencional, de la que brota este o aquel programa político tutelar de derechos y deriva, por añadidura, la justificación de la violación de este o aquel derecho fundamental.

Ve que lo que impulsa actualmente a violar el derecho a la vida es la difusión de una ética «lato sensu» empirista, cuya causa remota es la concepción individualista y abstracta de la persona humana. Lo que va desapareciendo en estas últimas décadas es la dimensión sapiencial de la vida individual y social, y, ello es debido al desinterés de enfrentarnos con la verdad de las cosas como fuente próxima de las leyes, y, por ende, con los principios de justicia y su fundamento. Justamente a este respecto en la EV. se recuerda que, cuando la libertad «no reconoce ni respeta su vínculo constitutivo con la verdad... la persona acaba por asumir como única e indiscutible referencia para sus propias decisiones no ya la verdad sobre el bien o el mal, sino sólo su opinión subjetiva y mudable o, incluso, su interés egoísta y su capricho» (n. 19).

El relator, a tenor de estas consideraciones, sostiene que la enseñanza de la Filosofía del derecho como derecho natural clásico es indispensable, si no se quiere renunciar a una valoración crítica que afronte al derecho positivo no respetuoso de la inviolabilidad de la vida y de la incoercibilidad de la libertad. 
20. La última relación del simposio cae a cargo del prof. de Filosofía del Derecho en la Facultad de Derecho en la universidad de MendozaArgentina, Carlos Ignacio Massini Correas: «Il diritto alla Vita nella sistematica dei diritti umani».

$\mathrm{Su}$ extensa ponencia intentaremos resumirla, evitando la reiteración de lo plasmado en las que le preceden.

En su introducción desea hacer algunas precisiones, la primera de ellas se refiere a la expresión «derecho a la vida», que estrictamente designa «derecho a la inviolabilidad de la vida». La segunda hace referencia a la expresión «vida», que designa precisa y exclusivamente a la vida humana, precisión oportuna, al existir una corriente de pensamiento que sostiene la existencia de derechos estrictos de los que son titulares entes no humanos.

Hechas estas aclaraciones entra en el desarrollo del tema. La noción de derechos humanos hace referencia que el fundamento de los mismos radica en la dignidad personal de todo ente humano y su contenido material viene dado por los bienes humanos básicos, que orientan la conducta de los hombres para escoger y obrar en ciertas y determinadas direcciones. Entre esos bienes humanos que especifican los derechos humanos está el derecho a la inviolabilidad de la vida. Este derecho ha de durar durante todo el tiempo de persistencia del bien, es decir, desde la concepción hasta su muerte. Desde el momento que exista un individuo que pertenece a la especie humana, debe existir también el derecho a que no se lo prive de nada. El ponente no acepta la dicotomía persona-individuo, por lo que se opone a esa corriente del pensamiento actual, como la de Engelhart entre otros, de que sólo son titulares de este derecho las «personas», cuya noción no es coextensiva con la de entes humanos, ya que existirían entes humanos que no son personas, v.g., los fetos, las criaturas, los retrasados mentales profundos y los que se encuentran en coma profundo. Estas entidades son (sólo) miembros de la especie humana. Las consecuencias de este pensamiento serían el establecimiento del principio de que la muerte de una persona puede ser moralmente lícita en ciertas circunstancias o dentro de ciertos límites, y aceptado este principio, todos estamos en peligro de ser asesinados.

Haciéndose eco de toda una serie de pensadores de origen anglosajón, sobre todo, pertenecientes a la escuela utilitarista, que sostienen que los derechos humanos son sólo derechos «prima facie», es decir, que pueden ser derogados, sobrepasados o suspendidos en el caso de que su respeto acarree consecuencias dañosas para el deudor o para la sociedad en general, manifiesta que este «derecho prima facie» no puede llamarse derecho, pues nadie puede «tomar en serio» un derecho que está sujeto a la condición suspensiva de que el deudor pueda no cumplirlo por razones 
de utilidad. Como consecuencia no existiría propiamente «derecho» alguno, pues todo derecho supone indefectiblemente la necesidad deóntica del cumplimiento de su objeto.

Del mismo modo, el derecho a la inviolabilidad de la vida se tiene o no se tiene: si el sujeto es un ser humano-persona, y no se dan ninguna de las causales eximentes de responsabilidad, v.g., la legítima defensa, ese sujeto tiene el título completo que funda la existencia de su derecho a la inviolabilidad de la vida.

Respecto a la ubicación de este derecho en el contexto sistemático de los derechos humanos, afirma que este derecho se encuentra en un rango superior al del resto de los derechos. A nivel especulativo, mientras los demás derechos se refieren a perfecciones humanas, que revisten un carácter existencialmente no autónomos, el valor básico de la vida hace referencia directa al modo de existir propio de los entes humanos, que es existencialmente autónomo o sustancial. A nivel práctico, la vida tiene un carácter especial en cuanto bien básico. Atentar a la vida implica un atentado indirecto al resto de los bienes humanos básicos, ya que su ausencia impide la posibilidad misma de su concreción.

Haciéndose eco del desprecio de la vida, cuyo fenómeno abarca una gran cantidad de dimensiones de la vida humana, considera que la razón fundamental radica en la ruptura, cada vez más radical, de cualquier referencia a un Ser absoluto y trascendente, fuente radical, por vía de participación, de la dignidad que compete a todo ser humano. La dignidad, en cambio que un hombre se confiere a sí mismo o le otorgan otros, desvanece apenas el mismo sujeto o los otros cambian de opinión respecto a esta dignidad, de forma que los derechos se transforman en «edictos de tolerancia esencialmente revocables» ${ }^{7}$.

21. Tras esta relación, sin debate posterior, se entrega a los congresistas un texto conclusivo en lengua italiana, que posteriormente es leído para su aprobación. Dada la premura de tiempo, según la presidencia, se omite hacer públicas las observaciones que se consideren pertinentes, instando a los congresistas que las depositen, llegado el caso, en la secretaría del simposio.

El texto es publicado en el L'Osservatore Romano ${ }^{8}$. En aras de la brevedad, intentaremos resumirlo.

A. Conclusioni dottrinali. Se afirma: 1. Que el único modo de fundar los derechos de la persona humana se encuentra en el ligamen entre libertad y verdad. 2. La EV. aprecia la democracia, el Estado de derecho

7 OR., 29 de mayo 1996, 6.

8 OR., 29 de mayo 1996, 6. 
y la cultura de los derechos humanos, reconduciéndolos a su auténtico fundamento y a su auténtica finalidad, que consisten, primariamente, en la defensa de la vida. 3. El derecho a la vida está en la base de todos aquellos valores humanos y morales esenciales y nativos que brotan de la verdad misma del ser humano y expresan y tutelan la dignidad de la persona. (...) Se augura que los ordenamientos jurídicos positivos se abran al reconocimiento de la plena dignidad del embrión humano y de sus derechos inalienables y procedan a elaborar las normas que garanticen la adecuada tutela a la vida humana prenatal, prohibiendo todas aquellas prácticas — incluso las de fecundación asistida - que amenazan la vida, la salud, el mismo patrimonio genético de los embriones. 4. Los participantes del simposio comparten no sólo en la firme condena de la EV. respecto a cualquier ley que atente al bien de la vida, sino también en la denuncia de tales leyes como injustas y privadas de auténtica validez jurídica. Auguran que tales ordenamientos jurídicos, en los que emanan las leyes contra el derecho a la vida, prevean expresamente la objeción de conciencia como un derecho de los médicos y, en general, de todos los operadores y responsables de las instituciones sanitarias. Auguran, también, que la objeción de conciencia no implique discriminación alguna en el orden académico y profesional.

B. Conclusioni per la vita accademica. 5. Se declara el convencimiento de la enseñanza del derecho natural y se deplora su vacío en muchas facultades jurídicas, pues con la expresión «derecho natural» se intenta el conocimiento que el derecho positivo no es suficiente por sí mismo, porque la justicia de sus normas no depende de la mera voluntad del legislador, sino de su arraigo en la verdad misma del hombre y de la coexistencia social. 6. Los participantes advierten el error de quienes consideran que el positivismo pueda reternerse científicamente y políticamente correcto y, en plena coherencia con la tradición secular, repiten que la reducción del derecho al mero derecho positivo y la negación del nexo constitutivo que une verdad, libertad y derecho es fatal para la existencia del derecho mismo. 7. Apelan, por lo tanto, a todos los docentes del derecho para que ofrezcan a los futuros juristas una sólida base de formación antropológica y ética, abierta al reconocimiento de los valores de la persona humana. Esta formación deberá contribuir y activar una nueva cultura de la vida. 8. Los participantes, conscientes de la necesidad de esta formación, requieren nuevos centros de estudio, incluso, interdisciplinares, congresos y seminarios y la publicación de libros y revistas.

C. Conclusioni socio-politiche. 9. Los participantes del simposio repiten las palabras del Santo Padre «respeta, ama y sirve a la vida, a toda vida humana» (EV. n. 5) e insisten por dirigir estas palabras, especial- 
mente, a los legisladores, a los jueces, a cualquier operador jurídico que tenga la autoridad de decidir sobre cuestiones de la vida humana a nivel local, nacional e internacional. 10. Los participantes de modo particular desean estimular a todos los hombres de buena voluntad, y cristianos en primer lugar, a defender la vida humana, aunque sea con graves esfuerzos y sacrificios. Saben bien la dificultad que existe, en casos concretos, para una mujer, incluso al límite heroico, acoger la vida que nace y para una familia asistir a un enfermo crónico o terminal y, en general, para todos asumir actitudes explícitas en defensa de la vida; pero desean recordar que en estas actitudes, incluso las del heroísmo, no hay nada de inhumano. 11. Piden a todos los juristas el compromiso sin pausa para que el derecho venga restaurado, para que las leyes injustas vengan reconocidas como tales y, en consecuencia, abrogadas. Auguran, además, que el art. 3 de la Declaración Universal de los Derechos del Hombre de la ONU venga plenamente acogido en todos los ordenamientos jurídicos positivos de los Estados del mundo. 12. Los participantes son conscientes que muchas actitudes hostiles al derecho a la vida provienen de órganos gubernativos y no gubernativos, que se hacen eco de una parte de la opinión pública. Pasan por alto, por desgracia, las convicciones morales de un número no menos consistente de personas o pueblos que, independientemente de la cultura y religión, son sensibles a la sacramentalidad de la vida y a su defensa. Auguran, por lo tanto, que los representantes de las naciones estén más atentos al sentido moral de tantos que consideran la vida como un valor humano fundamental que hay que respetar y defender. 13. Los participanes exhortan a los políticos a no adaptarse a criterios que contradicen los valores humanos y jurídicos fundamentales y especialmente a combatir las fuertes presiones a favor de una siempre mejor articulada legislación abortista y eutanásica (...) —en particular, a aquellos que con bravura («fiereza») debieran manifestar su identidad de católicos- a no tener miedo de declarar públicamente (...) su intención de ponerse al servicio de la vida y de asumir la verdad del hombre como norma y fundamento de su praxis en la materia, recordando la posibilidad que ofrece la EV. por promover iniciativas legales que miren a limitar el daño de las leyes abortistas y, en general, contrarias a la vida humana (n. 73c). 14. Los participantes conscientes de los egoísmos individuales y colectivos (...) auguran que todos los hombres tomen conciencia, incluso para desacreditar la falsa idea que las leyes contra la vida tengan sabor progresista y humanitaria. 15. Los participantes convencidos del rol de la mujer en la construcción de una nueva civilización del amor y de la vida, auguran un compromiso por parte de todos en pro de una transformación cultural a nivel universal, que asocie la defensa de la dignidad y de la libertad de la mujer con la de la vida humana. 


\section{Reflexiones}

El objetivo del simposio era, en palabras del Emmo. Cardenal Trujillo, reflexionar acerca de la incidencia que los principios morales sancionados en la Encíclica han tenido en nuestro mundo legislativo, jurisprudencial y académico.

El articulista Mario Ponzi manifiesta que desde el Simposio, en definitiva, han llegado indicaciones precisas para recuperar el pleno sentido de aquella cultura de la vida que algunos parecen renegar en nombre de una «democracia voluntariamente separada de la ética, que define la verdad sobre el hombre y la defensa de sus derechos inviolables "desde el punto de vista católico"» ${ }^{9}$.

Personalmente matizaría la expresión «democracia voluntariamente separada de la ética», a no ser que se afirme que la única ética que quepa denominarse como tal, sea la marcada por la filosofía aristotélica-tomista.

No nos agrada tampoco la expresión «desde el punto de vista católico», porque en ese caso reduciríamos la irradiación doctrinal de la Encíclica al mundo del catolicismo, cuando en realidad la Encíclica es «una acuciante llamada a todos y a cada uno, en nombre de Dios: ;respeta, defiende, ama y sirve a la vida, a toda vida humana! ${ }^{10}$.

Partiendo de la unidad doctrinal de las Encíclicas «Veritatis Splendor» y «Evangelium Vitae», el Simposio ha girado en torno al eterno problema del «Derecho natural». Y este problema en la conyuntura histórica que vivimos ha sido analizado tanto a nivel de información como formación desde los diversos ángulos del saber filosófico, ético, político, teológico y jurídico.

A nuestro entender, un tema de tanta trascendencia, como es el derecho a la inviolabilidad de la vida, demandaba oír voces de otras confesiones, solamente se nos informa del mundo musulmán, y, de expertos y peritos de la ciencia y del derecho que no compaginan con nuestros postulados. Hubiera sido más enriquecedor para todos los allí presentes.

Yendo al objetivo del Simposio, el querido y paciente lector de esta memoria caerá en cuenta que la incidencia de la Encíclica «Evangelium Vitae» ha sido más bien parca, por no decir nula, como se desprende de la comunicación de Mons. Minnerath. Hoy, como afirma el prof. Tarantino, se parte del individuo sin vínculos recíprocos, con sus derechos al margen de su relación con los derechos de los otros, o de una libertad

\footnotetext{
9 MARIo PonZI, «La difesa della vita umana no può essere considerata un semplice "punto de vista"», en L'Osservatore Romano, 29 de mayo 1996, 6.

${ }^{10}$ EV., n. 5,
} 
como «vínculo colateral», justificando un derecho positivo, que prevé y tutela los derechos fundamentales, en la medida en que son aceptados y propuestos por la vida acordada o convencional. Por ello, podemos decir que del primado del derecho sobre la política hemos pasado al primado de la política sobre el derecho (v. D'Alla Torre). En consecuencia, esta filosofía neopositivista lógico-jurídica produce en nuestro hábitat la «sociedad de excluidos» en los más diversos ámbitos (v. Serna).

Este primado de la política sobre el derecho está plagado de ambigüedades, sea a escala internacional como nacional, a tenor de lo que se desprende de la escucha y lectura de las ponencias y comunicaciones.

A nivel conceptual, no sabemos qué es ser "persona», qué es ser humano, qué es matrimonio, qué es familia, qué es maternidad, etc.; a nivel científico, nos invade las dudas del momento del nacer y del morir de la persona, ¿hasta dónde puede extenderse el campo de la ingeniería genética?; a nivel social, ¿es posible admitir la dicotomía individuo-persona, y en razón de esta dicotomía afirmemos que los así llamados individuos «no autónomos» (los fetos, los retrasados mentales, los terminales), no son personas y, en consecuencia, no tienen derecho a la inviolabilidad de la vida?; a nivel jurídico, ambigüedades en relación con la tutela de la vida, tanto en la legislación como en su interpretación y aplicación jurisdiccional.

No obstante, el panorama que se vislumbra, que para el prof. MayerMaly es sofocante y pésimo, deja algunos retazos de luz, pues la misma comunidad internacional desea renegociar una Declaración Universal de los Derechos del Hombre (v. Minnerath) y se siente converger acerca de la necesidad de establecer legítimamente un «estatuto del embrión» que establezca los confines y límites (v. D'Alla Torre). Leemos en uno de nuestros medios de comunicación que «Cuando la investigación científica no tiene limitaciones tecnológicas, es imprescindible que la sociedad regule sus avances», refiriéndose al diseño de un «vientre artificial», elaborado por dos equipos de investigadores del Reino Unido y Japón, en el que se podrían concebir y desarrollar fetos hasta el momento de su nacimiento. Y, siguiendo la lectura, se dice: «...para aprovechar su beneficio social sin desnaturalizar su esencia es necesario desarrollar una legislación que asegure que se emplean dentro de un marco ética y humanamente aceptable ${ }^{11}$. Por no hablar del rechazo de la mujer joven americana al feminismo oficial hacia el matrimonio y la maternidad, por su actitud antagónica respecto a los hombres, por su intolerancia a que se pueda disentir de su toma de posición en temas como el aborto o la homosexualidad (v. Glendon).

11 El Mundo, 18 de agosto, 1996, 4. 
Creemos que el respeto de la dignidad del ser humano sólo es posible si se respeta el orden de la creación, que, para los creyentes en Dios, se eleva, no se destruye, y se ilumina en el orden de la redención (v. Cafarra, D’Agostino, Serna). Desde estas coordenadas el hombre creado a «imagen de Dios» ${ }^{12}$ puede asumir responsablemente unas decisiones, «de modo que sepa buscar espontáneamente a su Creador» ${ }^{13}$. Posee un modo de sentir y de actuar que le pone en contacto a nivel de conciencia con los valores y con la verdad (v. Caffarra) ${ }^{14}$. Entre esos valores, emerge el valor de la vida, superior al resto de todos los valores, pues su inviolabilidad está indisolublemente unida a la dignidad de la persona.

La sustancia de este anuncio nos invita a la capacidad de querer y de sustraernos a la omnipresente tentación de ceder a la ciega (y por tanto violenta) neutralidad (v. D'Agostino). En un artículo referente a la eutanasia, citando al Card. Martini, decíamos: «Una cultura de la legalidad debe enraizarse en un profundo "ethos" personal y social. Las leyes deben respetarse no sólo por su valor formal o por las sanciones que conllevan su inobservancia (si así sucediera, entraríamos en el puro legalismo), sino también y, sobre todo, por su valor y significado intrínseco, por su capacidad de representar los ideales y fines de la colectividad, que no pueden ser otros que el desarrollo integral de la persona (legitimidad material) $)^{15}$ ».

Esta creencia no debe obnubilar, por otra parte, la realidad de la historia que nos toca vivir, asentada en el pluralismo como valor absoluto. Esta realidad llama a nuestras puertas y por nuestra parte debemos estar atentos a su llamada. ¿Cómo? Proponiendo y convenciendo, que en una sociedad, en la que nadie posee la verdad total, termina imponiéndose la voluntad del más fuerte. Por ello, evidenciamos que la ley, si es puramente humana, no puede ser principio fundante del orden ético, ya que ella misma está postulando unos principios metajurídicos de legitimación.

Esta demostración excluye caminos imperativos y exige caminos dialogantes (v. Glendon, Ollero), pues lo que se pretende es fundar una realidad nueva: ser todos hijos de Dios y, consiguientemente, todos hermanos (v. D' Agostino).

Confesamos sinceramente que esta vía dialogante no rezuma el texto conclusivo en lo que afecta al mundo académico como al mundo sociopolítico.

12 GS., n. 12

13 GS., n. 17

14 DH., n. 2

15 P.M. GARÍN, «El Derecho a vivir el morir», Estudios Deusto, vol. 41/2, julio-diciembre 1993, 105. 
Vienen a mi memoria las palabras del Card. Cardijn en el aula conciliar, cuando, se debatía la declaración sobre la libertad religiosa: «La confianza entre los hombres es una condición necesaria para la construcción de un mundo más humano (...). Si existen peligros en el régimen de libertad, ésos deben eliminarse mediante una acción positiva (...). La Iglesia no puede actuar como actuaba en el Medioevo o bajo los regímenes colonialistas (...) es necesario tener presente los valores educativos y pedagógicos de la libertad en la formación de los jóvenes, a los que no se debe impartir una educación basada bajo la coacción, sino una educación abierta basada en la libertad: ésta produce mayores responsabilidades ante Dios, capaces de obedecer siempre más a Dios que a los hombres» ${ }^{16}$.

En sintonía con lo que precede, no vemos en las «conclusiones para la vida académica» que la formación antropológica y ética se ofrezca en un régimen de libertad. Tienen más bien un acento dogmático, que, a nuestro entender, no responde a la misión docente. Esta sensación brota, también, de la lectura de las «conclusiones socio-políticas» (v. nn. 12-13). Es cierto que la EV. dice que frente a la ley moral objetiva no cabe «mayorías de opinión» ${ }^{17}$, pero creemos que estas «mayorías» reflejan un modo de sentir, que, aunque para nosotros puedan conducir al error, no por eso pierden su valor ${ }^{18}$.

Opinamos que en esta coyuntura del quehacer político no se trata de enterrar el juego de las mayorías, que en el pensamiento político contemporáneo es el menos malo, sino que, dentro de este juego, el político en temas que afectan directamente al ser o no ser de la sociedad, pues la vida constituye el fundamento de todos los otros bienes de la sociedad, sea libre de expresarse y de votar según conciencia, no sujeto a la dictadura interna del partido. ¿Es una utopía? Al político, que le conste con certeza la imposibilidad de esta utopía, entonces debemos recordarle el discurso «Con felice pensiero» de Pío XII, del 6 de noviembre de 1949, a la Unión de Juristas Católicos Italianos. El Papa se preguntaba si el juez católico puede o no puede sentenciar aplicando una ley o una norma de derecho que el mismo juez juzga como norma injusta. El Papa en su respuesta dice que al juez católico frente a la ley injusta le queda dos posibilidades, el de aplicar la ley en los casos en los que tal aplicación no sea una abdicación moral del juez, o renunciar a su puesto.

Aplicando la doctrina de Pío XII al poder legislativo, creemos que al diputado y, sobre todo, si es católico, cuando se trata de defender la dig-

\footnotetext{
16 II Concilio Vaticano II, en Cività Catolica, vol. V, p. 37.

17 EV., n. 70.

18 EV., nn. 26-27.
} 
nidad de la persona, el respeto de sus derechos inviolables e inalienables, le queda el derecho-deber de impedir toda ley contraria a la vida y, llegado el caso de la existencia de dicha ley y no poder evitar los daños de esa ley y así disminuir los efectos negativos ${ }^{19}$, presentar la objeción de conciencia, que debe ser protegida por la misma ley disciplinar del partido. Si así no fuera, es el mismo partido político que atenta al derecho de conciencia de su afiliado y, por ende, a su libertad, cuyo valor es resaltado como universal en todos los foros internacionales y nacionales.

De manera análoga extendemos este derecho a la objeción de conciencia «a los médicos, a los agentes sanitarios y a los responsables de las instituciones hospitalarias, de las clínicas y casas de salud» ${ }^{20}$.

\section{Audiencia del Papa Juan Pablo II}

Hacemos la observación que los destinatarios del discurso del Papa no solamente fueron los participantes del Simposio, sino también los que intervinieron en el XI «Colloquio internacionale Romanistico Canonistico».

Este congreso tenía como objeto la relación entre Etica y Derecho en el ámbito de la formación de los modernos ordenamientos jurídicos.

Aludimos a los puntos que consideramos que merecen resaltar:

3. El Papa, refiriéndose a la Encíclica «Evangelium Vitae», manifiesta que este documento ha intentado reafirmar la visión de la vida humana, que se desprende plenamente por la revelación cristiana, pero que, en su núcleo esencial, es alcanzable por la razón humana. Tras afirmar que la encíclica ha tenido en cuenta el enriquecimiento que la reflexión racional ha ido madurando al correr de los tiempos, dice: «De hecho, reconocer el valor de la vida del hombre, desde la concepción a su fin natural, es una conquista de la civilización del derecho, que debe ser tutelada como un bien primario de la persona y de la sociedad». Haciéndose eco de que en algunas sociedades contemplamos el regreso de esta civilización, fruto de una incompleta $y$, a veces, distorsionada concepción de la libertad humana, «sucede (...) que al respeto debido al inalienable derecho a la vida de todo ser humano se contrapone una concepción subjetivista de la libertad, desvinculada de la ley moral. Esta concepción, fundada sobre graves errores relativos a la naturaleza misma de la persona y de sus derechos, ha conseguido, valiéndose de las reglas mayoritarias, a introducir no poco frecuente en el ordenamiento jurídico la legitimación de la supresión del derecho a la vida de seres humanos inocentes aún no

\footnotetext{
19 EV., n. 73.

20 EV., n. 74.
} 
nacidos. Es útil, por lo tanto, poner de relieve, en prospectiva sea filosófica que jurídica, la íntima relación entre las Encíclicas "Veritatis Splendor" y "Evangelium Vitae" (...). Afirmar un derecho de la persona a la libertad, prescindiendo de la verdad objetiva sobre la misma persona, hace de hecho imposible la misma construcción de un ordenamiento jurídico intrínsecamente justo, porque es, en verdad, la persona humana —así como ésa ha sido creada - el fundamento y el fin de la vida social, a la que el Derecho debe servir».

4. Tras manifestar que la centralidad de la persona humana en el Derecho se expresa por el aforismo clásico «Hominum causa omne ius constitutum est» y recordar su observación hecha, con ocasión del décimo aniversario del nuevo Código de Derecho Canónico, de que el hombre redimido por Cristo es el centro del ordenamiento canónico, «de igual manera las sociedades civiles están invitadas por el ejemplo de la Iglesia a poner la persona humana al centro de sus ordenamientos, jamás sustrayéndose a los postulados del derecho natural, para no caer en el arbitrio de falsas ideologías. Los postulados del derecho natural son de hecho válidos en cualquier lugar y para cualquier pueblo, hoy y siempre, porque dictados por la "recta ratio" en la que, como explica Santo Tomás, está la esencia del derecho natural». Haciendo mención que este concepto había sido bien comprendido por el pensamiento jurídico clásico, $y$, citando a Cicerón, dice:

5. «Los elementos constitutivos de la verdad objetiva sobre el hombre y sobre su dignidad se enraizan en la "recta ratio", en la ética y en el derecho natural». Frente al humanismo ateo — continúa - es «deber del cristiano y, sobre todo, de los Pastores y de los teólogos, anunciar el Evangelio de la vida, según la enseñanza del Concilio Vaticano II. Este urgente compromiso interpela de modo particular a los juristas cristianos, impulsándoles a hacer emerger en los sectores de su competencia, el carácter intrínsecamente débil de un Derecho cerrado a la dimensión trascendente de la persona. El fundamento más sólido de toda ley que tutela la inviolabilidad, la integridad, la libertad de la persona reside, de hecho, en su ser creado a imagen y semejanza de Dios».

6. Haciendo presente los debates entre biólogos, moralistas y juristas referentes a los derechos humanos, reafirmando la doctrina de la Iglesia que el ser humano viene respetado y tratado como persona desde su concepción, reconociendo que la atribución del concepto persona pertenece al mundo de la filosofía - dice- «no podemos no asumir como punto de partida el estatuto del embrión, que es un individuo humano, teniendo la cualidad y la dignidad propia de la persona. El embrión humano tiene derechos fundamentales, es decir, es titular de constitutivos indispensables para que la actividad connatural a su ser pueda desarrollarse, "secondo un proprio principio vitale". 
La existencia del derecho a la vida, como constitutivo intrínsecamente presente en el estatuto biológico del individuo humano desde la fecundación, constituye, por lo tanto, el punto firme de la naturaleza, incluso, para la definición del estatuto ético y jurídico del "nascituro".

La norma jurídica, en particular, está llamada a definir el estatuto jurídico del embrión como sujeto de derechos, reconociendo un dato de hecho biológicamente inconfundible y en sí evocador de valores que no pueden ser descuidados ni por el orden moral ni por el orden jurídico.

Por la misma razón, considero un deber hacerme intérprete una vez más de estos derechos inviolables del ser humano desde su concepción, para todos los embriones que no raramente están sometidos a técnicas de congelación (crio-conservazione), llegando en muchos casos a ser objeto de mera experimentación o, peor, destinados a una programada destrucción con el aval legislativo.

Igualmente, confirmo como gravemente ilícito para la dignidad del ser humano y de su ser llamado a la vida, el recurso a los métodos de la procreación que la Instrucción "Donum Vitae" los ha definido como inaceptables por la doctrina moral.

La ilicitud de estas intervenciones sobre el inicio de la vida y sobre los embriones humanos ha sido confirmada; pero es necesario que se asuman también a nivel legal los principios sobre los que se funda la misma reflexión moral.

Apelo a la conciencia de los responsables del mundo científico y, de manera particular, a los médicos para que se paralice la producción de embriones humanos, teniendo cuenta que no se vislumbra una vía de salida moralmente lícita para el destino humano de los millones y millones de embriones congelados, los cuales son y permanecen para siempre titulares de los derechos esenciales y, por lo tanto de tutelarlos como personas humanas.

Los mismos gobernantes no pueden escaparse de este compromiso, para que se tutele desde sus orígenes el valor de la democracia, la cual funda sus propias raíces en los derechos inviolables reconocidos a todo individuo humano» ${ }^{21}$.

21 Juan Pablo II, Discurso rivolto ai partecipanti al Simposio su «Evangelium vitae e Diritto» e alla'XI Colloquio internazionale Romanistico Canonistico, en el OR., 25 de mayo, 1996, 5 . 